\title{
AVRUPA BIRLIĞi ÇERÇEVESINDE YEREL YÖNETIMLER VE GELIR YAPILARI
}

\author{
Yrd. Doç. Dr. Dillek Özkök Ģubukçu \\ Ankara Üniversitesi \\ Siyasal Bilgiler Fakültesi
}

\section{Özet}

Avrupa Birliğinde yerel yönetimler çoğu zaman bölgesel politika çerçevesinde üye ülkelerde gelişmişlik farkları gösteren ve bu nedenle bölgesel fonlardan yardım sağlayan ulusal yönetim birimleri olarak ele alınmaktadır. Bu çalışma kapsamında yerel yönetimler Birlik yönünden sadece bölgesel politika çerçevesinden değil aynı zamanda Birliğin kurumsallaşmış ilkelerinden yerellik ilkesi ve yerel kamu hizmetlerine yaklaşımı yönünden de ele alınmıştır. Öte yandan yerel özerkliğin en önemli unsurlarından olan ve son dönem Avrupası içinde sıkça tartışılarak yerel yönetim reformlarının başlıca hedeflerinden olan vergi özerkliği konusu Avrupa Birliğine üye ülkelerde yerel yönetimlerin gelir yapılarında karşılaştırmalı olarak incelenmektedir.

Anahtar Kelimeler: Avrupa Birliği, bölgesel politika, yerellik ilkesi, yerel kamu hizmeti, yerel yönetimler maliyesi.

\section{Local Governments and Revenue Structures within the European Union}

\section{Abstract}

Local governments within the European Union are generally being treated as national administrative units providing assistance using Regional Funds in order to avoid disparities of their economic developments. This study claims to consider local governments from the institutional "subsidiarity principle" and local public service perspectives of the European Union. On the other hand, there is an ongoing discussion about the tax autonomy of the local governments in Europe as a consequence of these discussions the last decades have been marked with some decentralization reforms in many European countries. There is no doubt that these movements affect directly the revenue structures of the member states. In this context, the financial relations between different levels of governments and the taxing powers of the local governments are the main concerns of this article. The discussion is largely based on countries' comparative experiences.

Keywords: European Union, regional policy, subsidiarity principle, local public services, local government finance. 


\section{Avrupa Birliği Çerçevesinde Yerel Yönetimler ve Gelir Yap1lar1}

\section{Giriş}

Kamu yönetimi reform çalışmalarının ülkemizde de sıklıkla gündeme taşıdığ 1 yerel yönetimler, vatandaşların demokrasileri ve gereklerini yakından izledikleri, yerel kamu hizmetlerinin daha iyi ve daha etkin sunulmasını sağlayan yönetim birimleridirler. Dünyadaki genel küreselleşme eğilimi, ilk bakışta çelişik gibi görünse de, beraberinde yerelleşme eğilimini de getirmektedir. Bu durumda Avrupa Birliği, bir yandan küresel düzenin en önemli aktörlerinden biri iken, kendi içinde önemli yerelleşme eğilimini de barındırmaktadır. $\mathrm{Bu}$ yönüyle oldukça önemli bir örneği oluşturmaktadır. Türkiye'deki yerel yönetimlere ilişkin reform çalışmaları bir yana, bugün Türkiye'nin Avrupa Birliği perspektifinde dahil olacağı coğrafyada diğer yerel yönetimlerin pozisyonundan bakmak oldukça ilginç olacaktır. Yerel yönetimlerin Avrupa Birliği için taşıdığı anlam ve Avrupa yerel yönetimlerinin mali açısından özellikle gelirleri yönüyle çizdiği tablo bu çalışmanın çerçevesini oluşturmaktadır.

\section{Avrupa Birliği Kurumsal Yapısı İçinde Yerel Yönetimlerin Yeri}

Avrupa Birliği kurumsal yapısı içinde yerel yönetimler için çerçeve çizen bazı temel kavramlar söz konusudur. Bunların ilki Birlik temel kurallarından biri haline gelen yerellik ilkesi diğeri de üye devletlerin yerel yönetimlerinin Birlik içinde temsil edildiği bir platform olarak Birlik organlarından biri olarak kurulan Bölgeler Komitesinin varlığıdır. Yerel yönetimler için önem taşıyan bu iki unsurun yanı sıra yerel yönetimlerin sunmuş olduğu yerel hizmetlerin Avrupa Birliği kurumsal yapısı içinde taşıdığı anlam araştırılmaya değerdir. 


\section{Yerellik (Ikincillik veya Subsidiarité') İlkesi}

Açık bir şekilde ilk kez Avrupa Birliği organlarının yasama ve yürütme faaliyetlerine bir hukuki çerçeve koyarak Maastricht Anlaşmasında karşımıza çıkan yerellik ilkesi, bu anlaşmanın 5'inci maddesinde kendisine yer bulmuş, daha sonra Amsterdam Anlaşması ile de geliştirilmiştir. Bugün Avrupa Birliğinin temel felsefelerinden ve kavramlarından birini oluşturmaktadır.

Üye devletlerin her birinde farklı önem ve boyutlara sahip ekonomik ve sosyal problemlerin çözüme kavușturulması açısından bir yaklaşım biçimine dönüşen bu ilke, kavramsal olarak, kamu hizmetlerinin daha etkin sunulabilmesini sağlamak üzere, vatandaşa yakın ve kamu hizmet taleplerinin doğrudan doğruya, daha demokratik olarak yansitılmasını sağlayan alt yönetim birimlerince üstlenilmesini öngörür. Hizmet bu birimler tarafindan yerine getirilemediğinde ya da yeterince etkin yerine getirilemediğinde daha üst kademe tarafindan üstlenilmelidir. Çok eleştirilen Avrupa Birliği bürokrasisini ("Eurokrasi”yi) disiplin altına alma yolu olarak da görülen yerellik ilkesi Avrupa Birliği kurucu anlaşmasında şu şekilde tanımlanmıştır:

"Salt kendi yetki alanına girmeyen konularda, Birlik, yalnız yerellik ilkesine uygun olarak hareket eder. Yeter ki, söz konusu önlemlerle varllmak istenen amaçlara, üye devletlerce daha iyi ulaşmak olanağ bulunmasın ve kapsamı ve etkisi açısından, bu konular Topluluk düzeyinde daha iyi ele alınabilsin" (madde 3B).

Hizmette halka yakınlık olarak da yorumlanabilen yerellik ilkesi, Birliği vatandaşlara yaklaştırması yönüyle de önem taşımaktadır. Buna göre Avrupa Birliği organları sadece, diğer halka yakın idari birimler tarafından hiçbir şekilde yerine getirilemeyen ya da yeterince iyi yerine getirilemeyen faaliyetleri yapabileceklerdir. Ancak anlaşmada tanımlandığ şekliyle yerellik ilkesi, üye devletlerle Avrupa Birliği arasındaki ilişkiler için geçerli olmakta, üye devletlerin kendi anayasal sistemleri içinde düzenlenmiş olan idari ilişkilere ise müdahale etmemektedir. İlke üç temel unsurdan oluşmaktadır ${ }^{2}$ : Birincisi

1 Kavramın yaygın kullanım biçimi haline dönüşen biçimi "yerellik" olmasına karşılık diğer biçimlerde kullanıldığına rastlanmaktadır. Latince kökeni "subsidium"olan ve "destek, yardım, rezerv" anlamını taşıyan subsidiarité kavramı ilk kez Katolik Kilise sosyal doktrininde (18 yy. Papa Leon XII) yer almıştır. Detaylı bilgi için bkz. Clergerie (1997):5; Le Cacheux (1996): 68. Kavramın Türkçeye aktarılışına ilişkin olarak bkz. Başaran Yavaşlar (2002): 353.

2 Avis du Comité des régions sur la Revision du Traité sur l'Union européenne, Rapporteur: Jordi Pujol, Bruxelles, le 21 avril 1995, http://europa.eu.int/en/ agenda/igc-home/eu-doc/regions/crf_fr.html (20/4/2006) 
- Ankara Üniversitesi SBF Dergisi • 63-1

demokratik meşruiyet ilkesidir. $\mathrm{Bu}$, Birliğin üye devletlerin vatandaşlarından uzak bir Avrupa merkezi otoritesi oluşturmasını engeller. İkincisi, şeffaflık ilkesidir ve kamu otoritesinin farklı seviyelerinde görev ve yetki paylaşımının açıça yapılması ile her vatandaşın hangi yönetim biriminin ne yaptı̆̆ hakkında bilgi sahibi olmasını sağlar. Üçüncüsü ise etkinlik ilkesidir ve faaliyetin yerine getirilmesinde yetkilerin en etkin olacak birime devredilmesi anlamını taşır.

$\mathrm{Bu}$ durumda yerellik ilkesi hizmetlerde önceliği halka yakın birimlere, etkinlik ölçütünü gerçekleştiği ölçüde vermekle birlikte, yerellik ilkesi, yerinden yönetim kavramıla mutlaka aynı anlama gelmemektedir ${ }^{3}$. Nitekim üye devletlere bırakılan kimi faaliyetler başarısız ya da yetersiz görülürse hizmetleri yerellik ilkesi gereği Avrupa Birliği de üstlenebilecektir. Ancak Birliğin müdahale alanı, doğal olarak, Birlik ortak çıkarlarına yönelik faaliyetlerle sinırlıdır. Dolayısıyla yerellik ilkesi Avrupa Birliğinin üye devletlerle olan yetki paylaşımının çerçevesini çizmektedir, ancak Birlik faaliyet alanı ile sınırlı bu yetki devletlerin kendi içlerindeki anayasal yetki paylaşımını kapsamamaktadır.

\section{Bölgeler Komitesi}

Parlamento, Komisyon ve Konseyin yanı sira, Ekonomik ve Sosyal Komite gibi Birlik danışma organı olarak kurulmuştur. Yerellik ilkesinin Avrupa Birliğinin hukuki kavramlarından biri ve Birlik felsefesi haline gelme tarihi ile Bölgeler Komitesinin danışma organı olarak öngörülme tarihleri örtüşmektedir. (Maastricht Anlaşmast-1992) Bu da Bölgeler Komitesi aracılığıyla yerel yönetimlerin Birlik içinde Avrupa için oynayacağı rol için önemli bir gösterge kabul edilebilir. 1994 y1lında faaliyetlerine başlayan Bölgeler Komitesi üye devletlerin idari yerinden yönetim birimlerinin temsil edildiği, danışma organı niteliğinde bir organdır. Maastricht Anlaşması, Konsey ve Komisyona, belirli konularda ${ }^{4}$ Bölgeler Komitesine danışmalarını zorunlu tutmuştur. Öte yandan 1 Mart 1999 tarihinde yürürlüğe giren Amsterdam Anlaşması yerellik ilkesinin Avrupa için öneminin altını çizerek, Bölgeler

3 Yetki paylaşımı ve yerellik ilkesi üzerine ayrıntılı bilgi için bkz. Document de travail L'Europe qu'il nous faut, 25 septembre 2001, http://europa.eu.int/futurum/ documents/other/oth250901_fr.pdf (18/4/2005)

4 Ekonomik ve sosyal yakınlaştırma, trans-Avrupa altyapı ağı, sağılı, eğitim ve kültüre ilişkin konularda Bölgeler Komitesine danışılması zorunluluğu bulunmaktadır. 
Komitesinin görev alanını genişletmiştir ${ }^{5}$. Ayrıca Komiteye danışması zorunlu Birlik organlarına Avrupa Parlamentosu da eklenmiştir. Buna göre, Konsey, Avrupa Parlamentosu ve Komisyon belirtilen konularda herhangi bir yasama faaliyeti veya eylem planı yaptıklarında Bölgeler Komitesine başvurmak zorundadırlar.

Alt komisyonlar (bölgesel uyum, ekonomik sosyal konular, sürdürülebilir büyüme, kültür ve eğitim, Anayasal sorunlar ve Birlik yönetişim, dış ilişkiler alt komisyonları gibi) ve çalışma grupları şeklinde çalışan Bölgeler Komitesi kendisine gelen konu ile ilgili hazırlanan görüş projesi raporunu oylayarak ilgili Birlik organına gönderir. Öte yandan zorunlu danışma alanları dışında Komite kendiliğinden uygun gördüğü konularda görüş bildirme yetkisine sahiptir. Yine Komisyon, Konsey ve Avrupa Parlamentosu, istedikleri takdirde, bölgesel ve yerel planda etkisi olduğunu düşünülen konularla ilgili olarak, Bölgeler Komitesinin görüşünü almak üzere başvurabilirler.

Birlik üye devletlerinin sayısının artması, yeni üye devletlerin idari yerinden yönetim birimlerini de bünyesine alacağı için, Bölgeler Komitesinin faaliyet alanının genişlemesi söz konusu olmaktadır. Bu durumda Birliğin temel amac1, köklerini yerel bölge, şehir veya birimlerinde arayan Birlik vatandaşlarının kendilerini Birlik içinde doğrudan temsil edecek Komite aracılığıyla ifade edebilmesini sağlamak olmuştur. Bu açıdan Komite Birlik üyesi ülkelerin halklarının Avrupa Birliği kurumlarında seslerini duyurmalarını ve karar alma sürecine katılmalarını sağlarken, bir yandan da Birlik kurumlarının faaliyetlerini Avrupa coğrafyası içinde dağılmış kentlere ve bölgelere ulaştırıp bir tür sözcülük ve aracılık faaliyetini yerine getirmektedir. Ancak bir "bölgeleştirme aracı" değil, ulusal devlet, bölge ve belediyeleri içine alan bir dikey işbirliği ile bölgesel ve yerel otoritelerin kendi aralarında bir yatay işbirliğinin geliştirilmesine çalışmaktadır.

26 Şubat 2001 tarihinde Birlik üye devletleri tarafindan imzalanan Nice Anlaşması ile Bölgeler Komitesine yapılan en önemli eleştirilerden biri giderilmiştir. Buna göre, daha önce üye devletler tarafindan önerilerek Konsey tarafından atanan Bölgeler Komitesi üyelerinin seçimle işbaşına gelmiş kişiler olması ya da demokratik yollarla seçilmiş bir yasama organına karşı siyaseten sorumlu olan kişilerden oluşması koşulu getirilmiştir (Esen, 2004: 119). Öte yandan, daha önce Bölgeler Komitesi üyelerinin ${ }^{6}$ atanmasında yetkili olan

$5 \mathrm{Bu}$ alanlar sosyal politika, istihdam politikası, çevre, mesleki eğitim ve ulaştırma olarak belirlenmiştir.

6 Üyeler Komiteye dört yıl için seçilirler. Komitede 222 üye ve yedekler bulunmaktadır. Nice Anlaşması ise üyelerin sayısını, yeni Birlik üyelerinin de katılımı sonrası, 
Konseyin, atanacak üyeler için, Nice Anlaşması ile oybirliği yerine nitelikli çoğunlukla karar alması koşulu getirilmiş̧ir. Anlaşma 2003 yılında yürürlüğe girmiştir.

Komite için getirilen ikinci önemli eleştiri ise, Komitenin Birlik karar alma mekanizması içinde, sadece danışma organı olarak, belirleyici bir rol oynamamasıdır. Komitenin görüş bildirdiği konuların sayısının, kuruluşunun izleyen kısa bir süre sonunda arttırılmış olması ve bu alanların $\mathrm{AB}$ için önem taşıyan önemli konulardan oluşması Komitenin rolü hakkında önemli göstergeler olmakla birlikte, karar organlarını bağlayıcı niteliği bulunmamaktadır. Ancak artık sadece ulusal kimlikleriyle değil Avrupa Birliği ile de özdeşleşmiş üye devletlerin yerel yönetim birimlerinin Bölgeler Komitesi ile temsil edilip sinırlı da olsa Birlik karar alma sürecine dahil edilmesi olumlu bir gelişme olarak nitelendirilmektedir (Esen, 2004: 119-120).

\section{Avrupa Birliği Bölgesel Politikası Çerçeve- sinde Yerel Yönetimler}

Avrupa Birliği bölgesel politikası, üye devletler arasındaki bölgesel gelişmişlik ve yaşam standartlarına ilişkin farkları mali dayanışma ile giderme fikrine dayanmaktadır. Üye devletlerin Birlik bütçesine yaptıkları katkıların bir bölümü bu amaçla Birliğin az gelişmiş bölgelerine aktarılmaktadır. Birlik alanı içinde az çok benzer düzeyde yaşam standardı sağlama ve az gelişmiş bölgelerin kalkınmalarına yardım etme "bölgesel politika" olarak Avrupa Ekonomik Topluluğunun kuruluşundan (1957) itibaren hedeflenmiştir.

İngiltere, İrlanda ve Danimarka'nın 1973 yılında Topluluğa üye olmasından sonra iyice belirginleşen bölgesel farklar nedeniyle 1975 yllında Avrupa Bölgesel Kalkınma Fonu oluşturulmuştur. Özellikle İngiltere'nin verimsiz geleneksel sanayi bölgeleri bu fonla desteklenmiştir. İspanya, Portekiz ve Yunanistan'ın 1986'da üye olmasından sonra bu ülkeler de fondan geniş ölçüde yararlanarak, Topluluğun daha gelişmiş ülke ve bölgeleriyle olan ekonomik gelişmişlik farklarının giderilmesinde katkılar sağlamışlardır.

1986 yılında yürürlüğe giren Avrupa Tek Senedi ile bölgesel "dayanışma" politikası kurumsallaşmıştır. 1992'de Maastricht Anlaşması ile

350 olarak sınırlandırmıştır. Birliğe 2004 yılında 10 yeni üye devletin katılımı sonrası üye sayısı 317 olmuş, 2007 yılı başında Romanya ve Bulgaristan'ın katılımı ile 344'e çıkmıştır. Ancak Nice Anlaşmasına göre hiçbir şekilde 350'yı geçemeyecektir. Komiteye üyeler arasından bir başkan ve yardımcısı seçilir ve bunlar Komiteye iki yıl başkanlık eder. 
Birlik temel amaçlarından biri haline getirilmiştir. Aynı zamanda ekonomik ve parasal birlik için öngörülen Maastricht kriterlerinin ekonomik ve bütçe kısıtlamalarının birbirine uyumlu ekonomileri yaratması önkoşulunda olduğu gibi, uyumlu bir kalkınma sadece ekonomik göstergelerin iyileştirilmesi ile sınırlı kalmayıp aynı zamanda bazı ülkelerde daha çok altyapı yatırımları yapılmasını da gerektiriyordu. İspanya, Yunanistan ve Portekiz gibi az gelişmiş üye devletlerin böyle büyük yatırımları yapabilmesi için Birliğin desteğine ihtiyaçları vardı. Bu nedenle sadece bu ülkelere yönelik mali destek sağlayan Uyum Fonu (Cohesion fund, Fond de cohésion) oluşturuldu. 1999 y1lında ise Amsterdam Anlaşması, bölgesel ekonomik yakınlaşmanın, Birlik ülkelerinde artan işsizlik ve sürdürülebilir büyümeyi sağlama gibi problemler nedeniyle, bölgesel istihdam politikası boyutunu da içerir hale gelmesini sağladı.

Çoğu doğu ve orta Avrupa devletlerinden oluşan yeni üye devletlerin varlı̆̆ 1 (ki bunların gayri safi hasıla bakımından Birlik ortalamasının epeyce altında olduğu bilinmektedir) Birlik içinde bölgesel heterojenliği arttıracağından bölgesel ve sektörel bazı düzenlemeler yapılması zorunlu olmaya devam edeceğinden Bölgesel Politika ve bölgesel politikayı destekleyen mali yardımlar sistemi Birlik için oldukça önem taşıyan bir konu durumundadır. Nitekim yeni üye ülkelerle Birlik nüfusu ve yüzölçümü \% 30 oranında, gayri safi hasıla ise sadece $\% 5$ oranında artmış durumdadır. Yeni üye ülkelerin toplam nüfusunun \% 98'i ise genişlemiş topluluk ortalama hasılasının \% 75 altında olan bölgelerde yaşamaktadır.

Çok uzun zamandan beri Birlik hedeflerinden biri olan bölgesel ekonomik ve sosyal dayanışma ve yakınlaştırma için Birlik her yıl bütçesinin üçte birini ayırmaktadır. Bu amaca yönelik olarak Komisyon iki büyük mali araca sahiptir. Bunlardan birincisi Yapısal Fonlar diğeri de Uyum Fonudur.

\section{Yapisal Fonlar (Fonds structurels)}

AB'nin gelişme süreci içinde çeşitli zamanlarda oluşturulmuş 4 ayrı fondan oluşmaktadır. Bunlar geri kalmış bölgeleri, ekonomik iyileştirme çabalarını ve yapısal zorluk içindeki sektörleri desteklemek için kullanılan Avrupa Bölgesel Kalkınma Fonu (FEDER), istihdama yönelik Avrupa Birliği stratejisi için kullanılan Avrupa Sosyal Fonu (FSE), tarımsal üretim etkinliğini arttırma, geri kalmış tarım bölgelerinin gelişimini destekleyecek yapısal düzenlemeler ve kalkınma amacı için Avrupa Tarım Yönlendirme ve Garanti Fonu (FEOGA), balıkçılık sektörünün yapısal gelişimi için Balıkçılığ Yönlendirme Mali Aracı (IFOP).

$\mathrm{Bu}$ dört Yapısal Fondan yapılan mali destekler yöneldikleri amaçlara göre Öncelikli Hedeflere ayrilırlar : 
- Hedef 1: geri kalmış bölgelere yönelik krediler. Kişi başına düşen GSMH's1 AB ortalamasının \% 75 altında olan bölgeleri ile Birlik deniz-aşırı bölgelerine (Fransa'nın denizaşırı départment'ları (DOM), Portekiz'in Azor Adaları ve Madeira ile İspanya'nın Kanarya Adaları) ve Avusturya, Finlandiya ve İsveç'in nüfus yoğunluğu az olan bölgelerine yapılan mali yardımlar bu hedef içinde yar alır. Yapısal fonların üçte ikisi Hedef 1 de yoğunlaşmaktadır. Birlik nüfusunun da \% 20'si kadar bir bölümü içine almaktadır.

- $\quad$ Hedef 2: Hedef 1in dışında kalıp ekonomik, sosyal ve yapısal güçlük içinde bulunan bölgelere yönelik mali destekleri içerir. Ekonomik zorluk içindeki sektörler, kırsal alanlar, balıkçılığa bağımlı ekonomik krizdeki bölgeler ve bazı krizdeki kentsel alanlar Hedef 2'nin müdahale alanına girmektedir. Birlik nüfusunun \% 18'i Hedef 2 ile ilişkilendirilmiştir.

- Hedef 3: Hedef 1 dışında kalan bölgelerde mesleki eğitim ve işgücünü geliştirme faaliyetleri ile ilgilidir.

Öncelikli hedefler dışında mali desteklerin bir bölümü de Birlik Inisyatifleri'nden yapılmaktadır. 1994-1999 döneminde onüç adet olan Ínisyatifler 2000-2006 dönemi için dörde indirilmiştir. Bunlar sınırötesi bölgesel ve ulusal işbirliğini arttırmaya, kırsal gelişime, istihdama ve sosyal ve ekonomik krizdeki şehir ve banliyölere yönelik yardım programlarıdır.

Yapısal fonlar bölgeler, üye devletler ve $\mathrm{AB}$ arasında işbirliği esasına dayalı gelişme stratejisi izlemektedir. Birliğin temel ilkeleri ve yönlendirmeleri çerçevesinde ulusal devlet ve bölgeler tarafindan yürütülürler. Yardımlar ulusal ve bölgesel öncelikler esasına göre hazırlanmış çok yıllık programlarla düzenlenir. Ancak bu programlar ulusal ve bölgesel kalkınma plan ve programlarının yerine geçmemekte, onlara ek olarak düzenlenmektedir. Üye devletler uygulanacak programı yönetip izleyecek bir idari otorite belirlerler. $\mathrm{Bu}$ idari birim programın y1llık olarak yürütülmesine ilişkin Komisyona gönderilecek raporları hazırlamak, etkinliğini takip etmek ve değerlendirmek, veri toplamak gibi faaliyetleri yürütür. İzleme komiteleri yoluyla programın denetimi üye devletlerin sorumluluğuna bırakılmıştır. Programlar için Komisyon, yardımdan faydalanacak üye devletlerle mali bir sözleşme yaparak yıllık olarak aktarılacak ödenek miktarını tespit eder. Üye devlet ise belirlediği ödeme merciinden ödenekleri kullandırır. Devlet muhasebe sisteminde olduğu gibi bu yöntemle, ödeme mercii ile idare mercii birbirinden ayrılmaktadır. Birliğin yerinden yönetim ilkesine uygun olarak programların yürütülmesi ve 
ödeneklerin kullandırılması konusunda üye devletlere verdiği yetkiye karşıllı her program için ayrıntılı mali denetimler uygulanmaktadır.

Yapısal fonlardan yapılan yardımlar genellikle geri ödemesiz ya da doğrudan yardım niteliğini taşımaktadır. Daha az olarak yardımların kredi, faiz indirimi, sermayeye katılım ya da risk sermayesi biçimini alması mümkündür.

Fonların program ve üye ülke bazında denetiminin yanı sıra, Komisyonun kendisi yapısal fonlar sebebiyle AB organlarının denetimine tabi tutulmaktadır. Bunun için her yıl Kasıma kadar, programlarla ilgili olarak Konseye, Avrupa Parlamentosuna, Ekonomik ve Sosyal Konseye ve Bölgeler Komitesine ayrıntılı olarak rapor sunmakla yükümlüdür. Yıllık rapor yanında, üç yılda bir sunulan programların sonuçlarının değerlendirilip Birlik içi ekonomik sosyal uyuma olan katkılarının tartışıldığı başka bir raporla da denetime tabi tutulmaktadır.

\section{Uyum Fonu}

Yapısal fonları tamamlayıcı nitelikte destekleme sağlamaktadır. Daha çok üye ülkelerin çevre ve ulaştırma altyapı yatırımlarını desteklemektedir. 1994'te kurulan bu fondan kullandırılan kaynaklar için ön koşul fondan yararlanacak üye ülkenin kişi başına gayri safi milli hasılasının Birlik ortalamasından \% 90 oranında düşük olmasıdır. Bu üye ülkelerden Maastricht kriterlerine uymak için program yürütenler için fondan kaynak kullanmak mümkün olmaktadır. Bu şartları bugün itibarıyla sağlayan üye ülkeler ise İrlanda, İspanya, Portekiz ve Yunanistan'dır. Üye ülkelerin çok yıllık yardım dönemleri içinde bu önkoşulu yitirmeleri durumunda yeni projeler ya da proje safhalarının fondan desteklenmesi imkanını ortadan kaldırmaktadır.

Üye devletler yardım talebi için ayrıntılı projelerini $\mathrm{AB}$ Komisyonuna sunarlar. Projede yatırım planı, yer, maliyet (en az 10 milyar $€$ ), projenin istihdama ve çevreye olan katkısı, ihale şartları gibi bilgiler bulunmalıdır ve yatırım bazı kriterlere uymalıdır?

Bu iki fon dışında Üyelik Öncesi Yapısal Araç (ISPA) adıverilen fon da bölgesel politika amacıyla kullanılmakta ve Birliğe alınacak olan orta ve doğu Avrupa ülkelerinin çevre ve altyapı koşullarını düzeltmeleri ve ulaşım altyapı ağını geliştirmelerini amaçlamaktadır. Üyelik Öncesi Tarımsal Araç (SAPARD)

7 Örneğin yapılan yatırımdan orta vadede elde edilecek ekonomik ve sosyal avantajların kullandırılacak kaynaklarla uyumlu olması, Birlik çevre politikasına katkı sağlaması, üye devletin öncelikleriyle uyumlu olması gibi şartları sağlamalıdır. 
- Ankara Üniversitesi SBF Dergisi • 63-1

denilen diğer bir fon da tarımsal kırsal alanda uzun dönemde Birliğe adaptasyon sorunu yaşayacak olan aday ülkeler için yaratılmış bir fondur.

Komisyonun yürüttüğü bu fon programlarının yanı sıra Avrupa Yatırım Bankası aracıllı̆ıyla da Birlik üye ülkelerinin entegrasyonuna yardımcı olmak ve az gelişmiş bölgelere katkı sağlamak üzere kaynak sağlanmaktadır. Avrupa Yatırım Bankasının çoğunluk ortağı olduğu Avrupa Yatırım Fonu, özellikle küçük ve orta ölçekli işletmelerin geliştirilmesi için kaynak temin etmektedir.

Hem finansal anlamda banka, hem de AB'nin resmi organlarından biri konumundaki Avrupa Yatırım Bankası'nın ortakları Birlik üyesi devletlerdir. Tüzel kişiliğe sahip Banka, Birlikten ayrı bir mali özerkliğe sahiptir. Uzun dönemli proje finansmanı sağlayarak üye devletlerin Birlik hedeflerine ulaşmalarına yardım etmektedir. Birlik içinde ekonomik ve sosyal yakınlaşma sağlanma, teknolojik yenilenme, çevre ve yaşam standartları ve kalitesi, aday ülkeleri üyeliğe hazırlama, ortak ülkelere kalkınma ve işbirliği geliştirme projelerinin finansman ihtiyaçları için Avrupa Yatırım Bankası önemli rol oynamaktadır.

Proje destekleri, küçük işletmelere yönelik genel amaçlı, aracı mali kurumdan geçen, 5-12 yıllık krediler, risk-sermayesi, 20 yıla kadar vadeli özel ve kamu sektörüne krediler ve "yapısal finansman mekanizması" yollarıyla sağlanmaktadır. Yapısal finansman mekanizması yüksek risk faktörü içeren bazı projelere çok çeşitli kredilerle destek verir. Daha çok ticari bankalardan veya sermaye piyasasından sağlanan kaynakları tamamlayıcı niteliktedir. Ama öncelikli projelerle ilgili olduğu için projelerden sağlanacak katma değer ve risk yüksek olduğu zaman kullanılan bir yoldur. Avrupa Yatırım Bankasının verdiği kredi desteklerinin büyük çoğunluğu üye ülkelerdeki veya üçüncü ülkelerdeki mali kurumlar eliyle dolaylı olarak sağlanmaktadır ${ }^{8}$.

8 Örneğin Avrupa Yatırım Bankasının bu anlamda Türkiye'deki partnerleri Vakıfbank, Türkiye Sınai Kalkınma Bankası'dır. Ancak yatırımcılara doğrudan doğruya da kredi sağlayabilmektedir. Banka kaynaklarından bugüne kadar Türk belediyeleri de çeşitli projeleri için yararlanmışlardır. Örneğin Eskişehir hafif raylı taşıma sistemi (2001), Mersin (2001), Bursa (2000), Tarsus (1999) su ve kanalizasyon altyapı iyileştirme, Diyarbakır (1998) ve Adana (1997) şehir suyu arıtma istasyonları, İzmit (1996) sanayi atık su arıtma, Ankara-ASKİ (1995) su -kanalizasyon arıtma gibi. Türkiye'nin kullandığı banka kaynaklarında özellikle 1995 sonrası artış görülmektedir. 


\section{Avrupa Birliğinin Yerel Kamu Hizmetlerine Yaklaşımı}

Avrupa Birliğinin gelişme sürecinin ilk dönemlerinde "kamu hizmeti" kavramı ne ulusal ne de yerel boyutu ile Topluluğun üzerinde tartıştığ 1 konulardan biri olmamıştır ve bu sebepledir ki Topluluğu kuran 1957 Roma Anlaşması konuya ilişkin hiçbir düzenleme getirmemiştir. Ancak serbest dolaşımın gerçekleşmesinden sonra ve ileriki aşamalarda kamu hizmeti kavramı özellikle de Fransa'nın çabalarıyla Avrupa Birliğinin gündemine, 1996'da Amsterdam Anlaşmasından sonra, Avrupa Topluluğunu kuran Anlaşmanın 16'ncı maddesi (eski madde 7D) ile girmiștir. İlk kez bu madde hükmü ile kamu hizmeti kavramı, kurumsal bir Topluluk Hukuku kavramı olarak kabul edilmiștir. Bu düzenlemeye göre üye devletlerin sosyal ve yerel olarak yakınlaştırılması için Birliğin üstlendiği rol ve kamu hizmetlerinin Birlik ortak değerleri içindeki önemi ışığında, "...Birlik ve üye devletlerin her birinin karşıllkll yetkileri ile anlaşmanın uygulama alanı dahilinde, Topluluk ve üye devletler bu[kamu] hizmetlerin[in], her birinin görevlerini yerine getirmelerini sağlayacak ilkeler ve şartlar temelinde, işlemesini gözetmekle yükümlüdürler"9.

Kamu hizmeti kavramı idare hukukunda, devlet ya da diğer kamu tüzel kişilerinin genel fayda sağlayan ve ortak ihtiyaçları karşılamak için sürekli biçimde ve düzenli olarak yaptıkları faaliyetlerdir ${ }^{10}$. Kamu hizmetlerinden yerel nitelikteki ortak ihtiyaçları sağlamaya yönelik olup yerel fayda sağlayanları ise

9 Bu hüküm her ne kadar kamu hizmeti kavramının Topluluk hukukuna girmekle bir anlam içermesine neden olsa da Fransa tarafından eleştirilmiştir. Fransa, 16' $\mathrm{ncl}$ madde hükmünün anlaşmanın "Topluluk temel ilkeleri" bölümüne konulmasını, hükmün doğrudan uygulanabilir olmasını engellediği ve sadece bir ilke bildirisi niteliği taşımaktan öte bir anlam ifade etmediği için eleştirmiştir. Ayrıca Amsterdam Anlaşmasına ek 13 no'u Bildirgeye eklenen ve kamu hizmetlerine ilişkin Anlaşma hükümlerinin kamu hizmetlerini kullanmada eşitlik, kamu hizmetlerinde kalite ve devamlılık ilkelerine ilişkin olarak uygulanmasında Adalet Divanı içtihatlarına tam uyum sağlanması hükmü nedeniyle de Fransa'nın eleştirisine maruz kalmıştır. Fransa'ya göre bu son hüküm, sistematik olarak kamu hizmetleri lehine karar vermeyen Adalet Divanı kararlarıyla içtihat oluşturulana kadar anlaşmaya eklenen yeni kamu hizmeti kuralları uygulamada üye devletlerin yorumlarına açık bırakılmış olmaktadır. Bunu gidermek üzere Fransa, Birliğin kamu hizmetleri ilkelerine ilişkin bir Avrupa Şartı'na önayak olmasını istemektedir Eleştiriler ve Şart önerisi için Bkz. Sénat (2001).

10 Kamu hizmeti kavramıla ilgili ayrıntılı bilgi için bkz. Onar (1952: 13). Ayrıca Günday (1997: 90) ve Gözübüyük (1991:7). Kamu hizmeti kavramının ayrıntılı analizi için Karahanoğulları (2002: 9-45). 
yerel kamu hizmetleridir. Kamu hizmetlerini diğer kamusal faaliyetlerden veya müdahale biçimlerinden ayırt etmek gerekmektedir. Bu nedenle kamu hizmeti, genel ekonomik denge sağlama veya sektörel destek biçimlerindeki müdahalelerden ve hukuki düzenlemelerden farklılaşmaktadır. Devlet burada ekonomik bir faaliyet içinde olmayıp düzenleme yapma yoluyla müdahale ile yetinmektedir. Halbuki kamu hizmetindeki temel ayrilık devletin ekonomik bir faaliyet yoluyla genel fayda sağlayan bir faaliyetinin olmasıdır. $\mathrm{Bu}$ anlamda herkesin fayda sağlayacağı, vazgeçilemez nitelikteki ve özel girişimin yapmak istemediği veya istemeyeceği, ya da yeterince iyi yerine getiremeyeceği faaliyetleri devletin üstlenmesi durumu belirleyici olmaktadır. Ancak bu durum devletin özel girişimin yerine geçmesi ve faaliyeti doğrudan doğruya üstlenmesi anlamını taşımayabilir (PE, 1997: W21). Çünkü devletin kendisi kamu hizmetini yapmak yerine bunu bir özel işletmeye ya da bir kamu işletmesine devredilebilir. $\mathrm{Bu}$ durumda bile devlet kamu hizmetinin tanımı ve içeriğine ilişsin her türlü sorumluluk ve yetkiye sahip olmaya devam etmektedir. Ayrıca devlet kamu hizmetini kurmada olduğu kadar ortadan kaldırmada da yetki sahibi olmaya devam edeceğinden devredilen bir kamu hizmeti de ancak devletin kendisi tarafindan ortadan kaldırılabilecektir.

Kamu hizmetleri uygulamada belirli temel ilkelere uygun olarak yerine getirilmektedir. Bunlar, gerek yerel gerek ulusal olarak kurulan kamu hizmetlerinin sahip olması beklenilen temel ilkeleri niteliğindedir. Klasik kamu hizmeti ilkeleri olarak da adlandırılan bu ilkeler eşitlik, devamlılık ve değişen koşullara kendiliğinden uyumdur (Karahanoğulları, 2002: 188). Eşitlik ilkesi kamu hizmeti kullanıcıları arasında hiçbir şekilde ayırım gözetilmemesi, herkesin aynı şartlarla ve aynı biçimde kamu hizmetinden yararlanması gerektiğini anlatır. Devamlılık ilkesi ise hizmetin sürekli ve düzenli olarak sağlanmasını ifade eder. Değişen koşullara uyum ilkesi ise kamu hizmetinin ihtiyaçlardaki değişikliği izlemesi ve ihtiyaç ortadan kalktığında hizmetin de ortadan kalkması gerektiğini ifade eder. Bu ilkeler kamu hizmetleri sunumunun ülke ekonomisi ve toplum üzerinde yarattığ 1 dolaylı etkilerin önemi ve kamu hizmetinin yapısal nitelikleri ile bağdaşır görünmektedir. Örneğin pek çok kamu hizmetinin doğal ve kıt kaynakları kullanması ve çok uzun dönemli alt yapı yatırımları gerektirmesi hizmetlerin devamlı olmasını ve değişen koşullara uymasinı zorunlu kılmaktadır ${ }^{11}$.

Ülkelerin ekonomik gelişmelerine paralel olarak artan ortak ihtiyaçlar, devletin olduğu kadar yerel birimlerin de yeni kamu hizmetlerini üstlenip harcamalarını arttırmalarına neden olmaktadır. Ancak kamu hizmeti

11 Les services d'intérêt général en Europe, JOCE C 281 du 26/9/1996. 
kavramında meydana gelen artış ve çeşitlenme nedeniyle, bazı kamu hizmetlerinin genel kuruluşu ve temel ilkeleri kamu hukuku çerçevesinde kalmakla birlikte uygulaması ve kişilerle olan ilişkileri yönünden özel hukuka bakmak gerekecektir (Günday, 1997: 90). Bu nedenle özel bazı hizmetler doğrudan doğruya devlet veya diğer kamu tüzel kişileri tarafindan yerine getirilmediği halde, bunların yakın gözetim ve denetiminde veya kamu hukuku düzeni içinde özel girişim tarafından yapılmaktadır.

Yerel yönetimler tarafindan kamu hizmeti yaratma yetkisi ulusal devletlerin her birinin anayasal düzeni ve yerinden yönetim kanunları ile sınırları çizilmiş bir yetkidir. Birlik üyesi ülkelerde yerel yönetimler çoğunlukla kendileriyle ilgili bölgesel ya da yerel alanlarda geniş ölçüde kamu hizmeti sunma yetkisine sahiptirler. Nitekim yerel ihtiyaçlar sebebiyle ortaya çıkan zorunlu yerel kamu hizmetlerinin tespitinin ulusal nitelikteki kamu hizmetlerine kıyasla daha açıça ortaya koyulabildiği düşünülmektedir (Guglielmi, 1994: 59). Buna göre zorunlu yerel kamu hizmetlerinin neler olduğu sıralanabilir çünkü bunlar zaten kanunlarla çerçevesi çizilerek merkezi devlet tarafından yerel birimlere bırakılmıştır. Kamu hizmetlerinin tamamı göz önüne alındığında, hizmetler temel fonksiyonlarına göre dört ana gruba ayrılabilirler. Güvenlik, asayiş ve adalet gibi devletin klasik fonksiyonlarından kaynaklanan hizmetler; eğitim, sağlık, sosyal güvenlik gibi aktiviteleri içine alan ve koruyucu devlet anlayışından kaynaklanan kamu hizmetleri, posta, ulaşım, enerji gibi alt-yapı ve ă̆ hizmetleri ve son olarak da yerel yönetimler tarafından yerine getirilen yerel hizmetler bulunmaktadır (Barbier vd. non daté: 9-10). Yerel kamu hizmetlerinin kendisini de dört temel grupta toplanmak mümkündür. Bunlar çevre koruma ve sağlık-temizlik hizmetleri, iletişim, enerji dağıtım ve ekonomik nitelikli faaliyetlerinden oluşur ${ }^{12}$.

Yukarıda teorik çerçevesini gördügümüz yerel kamu hizmetlerine Avrupa Birliği yaklaşımı daha tartışmalıdır. Bunun başlıca nedeni, yerel yönetimlerin kendisinin Avrupa Birliği politikaları -özellikle de bölgesel politika- ve hukuku içinde yer almasına rağmen yerel kamu hizmetlerinde benzer bir durumun açıkça görülmüyor olmasıdır. Birlik içinde bölgesel gelişmişlik farklarını gidermeye yönelik mali destekleme politikaları dışında, oluşturulan Bölgeler Komitesi ve Birliğin hemen her alanda altını çizdiği yerellik ilkesine rağmen, herhangi bir açık düzenleme bulunmamaktadır. Birliğin ilk dönemlerinde kamu hizmeti kavramı çoğunlukla "ulusal egemenlik" ve "kamu işletmeleri" kavramlarıyla bağlantılı görüldüğünden tamamen üye

$12 \mathrm{Bu}$ yerel hizmetlerle ve bunların gelişim süreçleriyle ilgili ayrıntılı bilgi için bkz. Auby (1982). 
devletlerin yetkisine bırakılmıştır. Bu kavramlar Roma Anlaşmasında açıç̧a yer verilen kavramlardan olamamıştır. Ancak Roma Anlaşmasının belli alanlardaki kamu hizmetleriyle ilgisi bulunduğu varsayılan düzenlemeleri bulunmaktadır. Örneğin malların serbest dolaşımı ve miktar kısıtlamalarıyla ilgili 30-34üncü maddeler, iş kurma hakk1 ve hizmetlerin serbest dolaşımılla ilgili 52-59üncü maddeler ve rekabet ile devlet yardımlarına ilişkin $85-86$ ve 92-94üncü maddeler ${ }^{13}$. Bunlar serbest rekabete ve dolaşım özgürlügünü sağlamaya yönelik temel prensip ve yasaklamalarla ilgili olup, buna ilişkin istisna hükümlerini de içermektedirler. Ancak genel olarak uyrukluk ölçütü ile üye devletler arasında yapılan her türlü ayırımcılığın üye devletler tarafindan engellenmesi yükümlülüğü ve rekabet bozucu faaliyet ve işlemlere getirilen yasakları ele alan düzenlemeleri içermektedirler. Nitekim istisna hükümlerinin çoğunlukla kamu yararını sağlamaya yönelik veya kamu hizmetleri sunulması ile doğrudan bağlantılı olduğu görülmektedir (PE, 1997: W21). Örneğin kamu sağlı̆̆ 1 ve güvenlik sebebiyle serbest dolaşım hakkına sınırlama getirme yetkisinde olduğu gibi. Öte yandan ticari nitelikteki devlet tekelleri, kamu işletmeleri ve rekabet kurallarına ilişkin olup kamu hizmetleri için belirleyicidir. Bu tekellere girdi ve işgücü sağlamak yönünden üye devletlerin uyrukluğa dayalı ayırımcılığı önleyen her türlü tedbiri alması ve gerekli hukuki düzenlemeleri yapması yükümlülüğü kamu hizmetleri için oluşacak temel sınır durumundadır (Topluluk Anlaşması md.31). Diğer yandan Topluluk Anlaşmasının 295'nci maddesi "işbu anlaşmanın üye devletlerin mülkiyet rejimlerine bir etkisi bulunmamaktadır" ifadesi ile kamu ve özel mülkiyet ile ilgili herhangi bir ayırım gözetmemiş ve kamu otoritesinin birlik felsefesini oluşturan rekabetçi düzen içinde yer alması gerektiğinin dolaylı olarak bir kez daha altını çizmiştir ${ }^{14}$.

Birliğin kurucu anlaşma metinlerinde daha açık olarak kamu hizmetinden söz edildiğini ise 73'üncü maddede görmek mümkündür. 73'üncü madde düzenlemesinde, ulaştırma giderlerinin koordinasyon gereksinimlerine yönelik olarak yapılan veya kamu hizmeti kavramı ile özdeşleşen bazı hizmetlere ilişkin

13 Roma Anlaşmasının sözü edilen bu maddeleri Konsolide Topluluk Anlaşmasında miktar kısıtlamalarıyla ilgili 28-31'inci maddelerde; iş kurma hakkı ve hizmetlerin serbest dolaşımıyla ilgili 43-59'uncu maddeler;

14 Maddenin ifade ettiği anlam iki yönlü olarak düşünülmelidir. Bir yandan kamu işletmelerinin Birliğin temel rekabetçi felsefesine uygun olarak pazarda faaliyet göstermelidir, diğer yandan da anlaşma, üye devletlerin mülkiyet rejimlerine müdahalede bulunamayacağı için kamu hizmeti yürüten kamu işletmelerini özelleştirmeleri konusunda üye devletleri zorlamamalıdır. Böylece gerek kamu gerek özel işletmeler yönünden anlaşmanın tarafsızlığı korunmuş olacaktır. 
geri ödemeler biçimindeki yardımların Antlaşma kapsamına gireceğinden söz edilmektedir. Öte yandan Anlaşmanın rekabete ilişkin düzenlemeleri de kamu hizmetleri konusunda kayda değer bulunmaktadır. Anlaşmanın 86'ıncı maddesinde rekabetle ilgili anlaşma kurallarının genel ekonomik fayda sağlayan hizmetlerin idaresinden sorumlu işletmeler ve mali tekel durumundaki işletmeler için de kural olarak geçerli olacağı, ancak bu kuralların bu işletmelerce hukuken veya fiilen yüklenilen özel görevi yerine getirmelerine engel olmaması durumunda söz konusu olacağından bahsedilmektedir. $\mathrm{Bu}$ durumda 73̈̈ncü maddedeki kamu hizmeti kavramı ulaştırma faaliyetleri için bu kamu hizmetine bağlı olarak ortaya çıkan yükümlülükler ile bağlantılı olarak, 86'incl madde ise genel ekonomik fayda yaratan hizmetler olarak kullanılmaktadır. Özellikle rekabet kurallarına ilişkin 86'ıncı maddenin kamu hizmetleri yönünden önemi kamu yararı gibi bazı durumlarda devlet tekeli durumundaki işletmelerin rekabet kurallarının istisnasını oluşturabilmesi ile vurgulanmaktadır. Ancak bu imkan üye devletlere doğrudan doğruya yaratılmış bir imkan olmayıp, maddenin devamında belirtildiği üzere, Komisyon tarafından gerek duyulduğunda direktifler veya kararlar yoluyla çerçevesi çizilmiş bir istisna uygulaması olacaktır. 86' $\mathrm{n} \mathrm{ncl}$ maddede belirtilen kamu işletmelerinin anlaşmada belirtilen rekabet şartlarına uymas1, 81ve 82inci maddelere göre işletmeler arasında ittifak, anlaşmalar veya her türlü işbirliği yoluyla ya da, işletmenin pazarda hakim durumun kötüye kullanması sonucu üye ülkeler arasında ticareti etkileyen ve ortak pazarın işleyişini ve rekabeti bozucu etki yaratan uygulamalara ilişkin yasağı kapsamında yer almaları beklenmektedir. Aynı zamanda rekabet kurallarından devlet yardımlarıyla ilişkili olanları da kamu işletmelerine uygulanır durumdadır. Bu düzenlemeler üye devletlerin yetkisine bırakılmış olan kamu hizmeti kavramı için yine de bir "Birlik sınırı" konulduğunu göstermekte ve örneğin kamu hizmeti sunan bir işletmeye Birlik rekabet düzenini bozucu olarak devlet yardımları verilip verilmediğini denetleme imkanını vermektedir. Bu konuya ilişkin olarak 25 Haziran 1980 tarihli 80/723 sayıl1 "üye devletler ile kamu işletmeleri arasındaki mali ilişkilerde şeffaflık direktifi" 15 kamu işletmelerine yapılan sermaye katılımı, sübvansiyon veya borç gibi doğrudan yardımlar ile borç garantisi, vergi avantajı gibi dolaylı devlet yardımları hakkında üye devletler tarafindan düzenli olarak bilgilendirilme ve muhasebe şeffaflı̆̆ gibi Komisyonun devlet yardımlarını kontrol edebileceği mekanizmalar öngörmektedir.

Birlik anlaşmalarının yanı sıra tüzük ve direktifler, Komisyon ile Konsey ve Adalet Divanının kararları da benzer şekilde tek bir kamu hizmeti kavramı

15 JOCE L 195, 25/6/1980. 
- Ankara Üniversitesi SBF Dergisi • 63-1

kullanmak yerine bu ve buna benzer kavramlara atıfta bulunmaktadır. Örneğin "genel faydalı hizmetler" (services d'intérêt général), ticari olsun olmasın, kamu otoritelerince genel fayda yarattığı düşünülen ve bu nedenle kamu hizmeti anlamında belirli yükümlülükler getiren faaliyetleri anlatmak için kullanılmaktadır. $\mathrm{Bu}$ anlamda genel faydalı hizmetleri, 86' incı maddede kullanılan "genel ekonomik faydalı hizmetler"den (services d'intérêt économique général) ayıran temel unsur faaliyet sektöründen kaynaklanmaktadır. Genel ekonomik faydalı hizmetler, ağ biçiminde sunulan ve çoğunlukla özel sektörün güçlükle sağlayabileceği büyük sanayi yatırımları gerektiren ulaşım, enerji ve haberleşme gibi ticari nitelik taşıyan hizmetlerdir. Son dönemlerde Komisyonun sıkça kullandığ1 "evrensel hizmet" (service universel) ise Anglo-sakson terminolojiden gelmektedir. Bu kavram her yerde ve herkesin kullanımına açık bazı temel hizmetlerinin uygun fiyatta ve mümkün olan en iyi kalitede sunumunu anlatmak için kullanılmaktadır. Örneğin, rekabete son derece açık haberleşme sektörü faaliyetleri için Komisyon bu kavramı tercih etmektedir. Ancak daha genel bir anlam yüklemesiyle Topluluk hukuku ve Komisyon "genel ekonomik faydalı hizmetler" kavramına aynı anda idare hukukunun "ticari ve sinai nitelikli kamu hizmetleri" ("service public industriel et commercial ") ile daha çok ekonomik bir bakış açısıyla "kamu ağ hizmetleri" ("services publiques de réseaux") anlamlarını yüklemektedir (Senat, 2000). Birliğin rekabet kurallarının uygulanması yönünden kamu ve özel sektör hizmetleri bakımından ilke olarak belirlediği tarafsızlığın sonucunda tüm bu kavram çeşitliliğinden, kamu hizmeti kavramının tanım sorunundan çok, kamu hizmetlerinde içerik belirlemesi sorunu olduğu ortaya çıkmaktadır.

1996 yılında Birliğin genişleme sürecinde geleceğin Avrupası şekillendirilirken açık ve dinamik bir Pazar ekonomisinin ancak eşitlik ve dayanışma ile mümkün olacağı ve bu iki unsurun da herkesin uygun karşılıklar ödeyerek kaliteli kamu hizmetlerinden faydalanması ile sağlanabileceği ifade edilmişti. Böyle bir yaklaşımda genel faydalı kamu hizmetleri neredeyse "sosyal hak" niteliği kazanmakta ve üye ülkelerin hem kendi içlerinde hem de birbirleriyle uyumlu ekonomik ve sosyal kalkınmalarına katk1 sağlayacağ 1 düşünülmektedir ${ }^{16}$. Komisyon, yerellik ilkesi çerçevesinde, her üye devlet tarafindan ekonomik, kültürel, sosyal ve tarihi olarak ortaya çıkan kamu hizmeti anlayışındaki çeşitliliği korumaya yardımcı uluslarüstü bir otorite olarak görev üstlenmektir. Öte yandan genel çerçevesi Birlik anlaşmasının yukarıda sözü edilen maddelerinde çizilmiş temel kurallarına uygun genel faydalı kamu hizmetlerinin Birlik içinde daha etkin ve daha iyi kaynak dağılımı

16 Les services d'intérêt général en Europe, JOCE C 281 du 26/9/1996. 
ile yapılmasını gözetmek de Komisyonun yetki alanında bulunmaktadır. Birlik bazı kamu hizmetlerinin yapısal özellikleri nedeniyle özel düzenlemeler içinde ele almıştır. Bu düzenlemeler evrensel hizmet kapsamında düşünülen hava ve demiryolu ile ulaşım, posta ve telekomünikasyon ile elektrik enerjisi hizmetlerine ilişkindir. Büyük ağ hizmetleri olarak tanımlanan bu hizmetler için üye devletlerce uyulması gerekli ortak ilkeler saptanmıştır. Öte yandan kurucu anlaşmalarda açıkça Birliğe bırakılarak müdahale biçimi tanımlanmış olan ortak pazar, rekabet, serbest dolaşım, devlet yardımları, çevre, sağlık ve sosyal politika gibi alanlarda da Birliğe müdahalede bulunma yetkisi tanınabilir. Genel faydalı kamu hizmetlerinin kurulması, örgütlenmesi ve denetimi konularında asli görev ise, Birlik temel ilkelerine aykırılık göstermemek şartıyla, merkezi ve yerel yönetim otoritelerine bırakılmıştır. Topluluk hukuku içinde bazı hizmetlere yönelik sektörel bir anlam içeren kamu hizmetlerinin konusu ulusal ve yerel boyutta ele alınmaktadır. Komisyonun genel faydalı kamu hizmetleri hakkında yayınladığı Yeşil Kitap'ta kamu hizmetlerine yönelik olarak Birlik ortak paydalarına uygunluk, hizmetlerde evrensel hedefler, hizmet devamlılı̆ 1 ve kalitesi, hizmetlerin herkese ulaşmasını sağlayan uygun fiyat ilkesi ve tüketici ve hizmet kullanıcılarının korunması olarak belirlenmiştir ${ }^{17}$. Kamu hizmetinin ilgili olduğu alanın niteliğine bağlı olarak bu temel ilkeler başka ilkelerle de tamamlanabilmektedir. Örneğin enerji sektörüne ilişkin olarak arz güvenliği sağlama ilkesi ya da rekabete açılan ağ hizmetlerinde (telekomünikasyon, demiryolu, şehir içi metro, otobüs hizmeti, gaz dağıtım, vs.) ağa giriş ve ağlar arası bağlantı (interconnexion) izni verme ilkesi gibi.

Kamu hizmetlerinde olduğu gibi yerel kamu hizmetleri konusu da anlaşma metni içinde kendine açıkça bir yer bulmamışken, kamu otoritesi kavramı kamu tüzel kişiliği kavramında yerinden yönetim birimlerini de kapsayacak şekilde ele alınmaktadır. Bu nedenle anlaşma serbest piyasa anlayışı ve rekabet şartlarıyla sadece üye devletleri, kişi ve kurumları ele alan düzenlemeler yapıyor görünse de Adalet Divanının pek çok kararında vurguladığ1 gibi devlet kavramı yerel yönetimleri kapsayacak şekilde ele alınmaktadır (Bettinger, 1994: 229-230). Yerel yönetimler aynı zamanda birlik hukukunun bir parçası olarak birlik düzenlemelerinin ilgili olduğu taraflardan biri ve politikaların tek başına veya ulusal devletle birlikte yürütücüsü (örneğin bölgesel politika alanında) konumundadır. Bu nedenledir ki yerel yönetimlerin, kuruluşundan itibaren Adalet Divanına, dava yoluyla ve doğrudan başvurma hakkı hiç tartışmasız öngörülmüştür (Pougnaud, 1992: 63). Nitekim yerel yönetimlerin kamu otoritesi niteliği 80/723 sayılı şeffaflık direktifine de konu 
- Ankara Üniversitesi SBF Dergisi • 63-1

olmuştur. Direktifin 2'inci maddesi devlet ile birlikte yerel yönetimleri kamu otoritesi olarak tanımlamakta, kamu işletmesi kavramından söz ederken bunların kamu otoritesinin doğrudan ya da dolaylı olarak mülkiyet hakkına, sermaye ortaklığına veya bu işletmelere uygulanacak kuralları koyma yetkisine sahip birimler olarak ele almaktadır. Benzer şekilde Adalet Divanında oluşan içtihatlar da bu durumu açıklayıcı niteliktedir. Örneğin 10 Mart 1987 tarihli 199/85 sayılı ("Commission v. République italienne") davada, yerel yönetimin işlediği kusur açıkça devletin işlediği kusur olarak nitelendirilmiştir (Bettinger, 1994: 230). Öte yandan Avrupa Anayasas1 metninin I-5 maddesi, linci fikrasinda ise ilk defa "yerel ve bölgesel özerklik"'ten bahsederek üye devletlerin sadece ulusal boyutta değil yerel ve bölgesel kimlikleriyle varolduğunun altını çizmektedir ${ }^{18}$.

Bölgeler Komitesinin genel faydalı kamu hizmetlerine ilişkin Yeşil Kitap hakkındaki yayınladığı raporda da belirttiği gibi, bu hizmetlerin tanımı, kapsamı, mali yöntemi ve denetimi ile ilgili olarak yerel ve bölgesel yönetimlerin oynadığı rol son derece önemlidir. Bunların bireylere en yakın kamu birimleri olan yerel ve bölgesel yönetim birimleri tarafindan daha iyi değerlendirilebilmesi Birlik tarafından öngörülen temel hedeflere ulaşmak açısından da kayda değer görülmektedir ${ }^{19}$. Bu nedenle genel faydalı ekonomik hizmetler kavramı Avrupa Birliği Anayasa taslağına da girmiş bulunmaktadır. Taslağın Birliğin işlevi ve politikalarına ayrılmış ikinci bölümünün genel uygulama hükümleri içinde yer alan III-6 maddesi, Birlik içi yerel ve sosyal yakınlaştırma için kamu hizmetlerine olan ihtiyaca vurgu yaparak, Amsterdam Anlaşmasının 16'ncl maddesinde yer alana benzer bir düzenlemeye yer vermektedir. Buna göre ulaştırma ve rekabete ilişkin kurallar saklı kalmak üzere "Birlik ve üye devletler kendilerine düssen yetkiler dahilinde ve Birlik Anayasasının uygulama alanı içinde, hizmetlerin ekonomik ve mali nitelikli ilke ve şartlar temelinde işlemesini sağlayarak kendilerine düşen görevi yerine getirmekle yükümlüdür. Kamu hizmetlerine ilişkin ilke ve şartlar Avrupa[Birlik] kanunu ile tanımlanır" ifadesini kullanmaktadır. Anayasa tasarısına eklenen bu son cümle ile kamu hizmetlerinin Birliğinin gelecekteki politikaları içinde kurumsallaştırılması yönünde perspektifi olduğu anlaşılmaktadır.

18 Anayasanın Tanım ve Birlik Temel Hedefleri bölümündeki Birliğin üye devletlerle ilişkilerini tanımlayan I-5 maddesi linci fikrasında Birliğin "bölgesel ve yerel özerklik de dahil olmak üzere, anayasa ve temel siyasi yapllarına uygun ulusal kimleri ile üye devletlerin Anayasa karşısında eşitliğini" gözeteceğini garanti etmektedir.

19 Avis du Comité des Régions, ECOS-019 du 20/11/2003. 
Uygulama açısından ise, Tablo I'de ayrıntılı olarak görülebileceği gibi, Birlik üyesi her ülkenin merkezi devletle olan geleneksel görev ve yetki paylaşımına uygun olarak değişmekle birlikte, yerel kamu hizmetleri büyük çoğunlukla sosyal güvenlik, sosyal yardım, genel kamu hizmeti niteliğindeki yerel hizmetler, eğitim ve sağlık hizmetleri alanlarında yoğunlaşmaktadır. Ülkeler arasında önemli farklılıklar da görülmektedir. Örneğin, İngiltere ve Fransa'da yerel yönetimler sağlık harcaması yapmazken veya çok az yaparken, İrlanda'da yerel yönetimlerin en önemli harcama kalemini sağlık harcamaları oluşturmaktadır. Danimarka, İsveç gibi kuzey Avrupa ülkelerinde ise geleneksel olarak yerel yönetimlerin sosyal yardım ve sosyal güvenliğe ilişkin harcamalar yaptığını, Fransız kamu hizmeti anlayışının yansıması olarak da Fransız yerel yönetimlerinin daha çok genel kamu hizmetleri sunumuna yöneldikleri görülmektedir. Üye ülkelerde yerel kamu hizmetlerinin sayı ve çeşitliliğindeki artışın her zaman yerel özerkliğe doğrudan olumlu etkide bulunmadığını belirtmek gereklidir. Çünkü hem üye ülkelerin hizmetlere ilişkin yerel otoritelere yetki devri ile birlikte artan kural ve denetimleri hem de Birliğin temel ilke ve kuralları, yerel kamu hizmetlerine ilişkin karar mekanizmasının belirli bir ölçüde yerel yönetim birimlerinden merkezi yönetim ve Birliğe kaydırma sonucu yaratmaktadır ${ }^{20}$.

20 Örneğin, merkezi devletin özellikle eğitim ve sağlık hizmetlerini büyük ölçüde yerel yönetimlere devrettiği ülkelerde, merkezi devlet hizmete ilişkin sıkı bir uygulama çerçevesi çizmekte ve denetlemektedir. Birlik ise temel ilke ve kurallara uygunluk ve özellikle rekabet kuralları ve devlet yardımları yönünden Adalet Divanının yerine getirdiği denetimler ile etkili olmaktadır. Bu açıdan yerel yönetimlerin sundukları yerel hizmetlerin Birliğin kamu ihalelerine ilişkin kuralları yönünden incelendiği ve yerel yönetimler aleyhine sonuçlanan Adalet Divanı kararları üye devlet yerel yönetimlerince yerellik ilkesi ve yerel özerkliği zedelediği için eleştirilmektedir. Bu yöndeki Adalet Divanı kararları için bkz. C- 107/98 Teckal Srl v. Comune di Viano et AGAC (Azienda Gas-Acqua Consorziale) Reggio Emilia, ECJ 18/11/1999 (Rec.1999, p.1-8121), C-231/03 Consorzio Aziende Metano (Coname) v. Comune di Cingia de' Botti ECJ 21/7/2005 (Rec.2005,p.I-7287), C-458/03 Parking Brixen GmbH v. Gemeinde Brixen \& Stadtwerke Brixen AG ECJ 13/9/2005 (Rec.2005,p.I8612). 
Tablo I AB Ülkelerinde Yerel Yönetim Harcamaları (2001)

\begin{tabular}{|l|c|c|c|c|c|c|c|c|c|}
\hline & $\begin{array}{c}\text { Genel } \\
\text { Kamu } \\
\text { Hizmeti }\end{array}$ & $\begin{array}{c}\text { Kamu } \\
\text { Düzeni } \\
\text { ve } \\
\text { Güvenlik }\end{array}$ & Eğitim & Sağlık & $\begin{array}{c}\text { Sosyal } \\
\text { Güvenlik } \\
\text { Sosyal } \\
\text { Yardım }\end{array}$ & $\begin{array}{c}\text { Konut ve } \\
\text { donanım }\end{array}$ & $\begin{array}{c}\text { Ulaşım ve } \\
\text { Haber- } \\
\text { leşme }\end{array}$ & Diğer & $\begin{array}{c}\text { Top- } \\
\text { lam }\end{array}$ \\
\hline Almanya & 7,4 & 3,4 & 13,0 & 14,5 & 24,6 & 15,3 & 6,0 & 15,9 & 100 \\
\hline Avusturya & 17,6 & 1,9 & 16,1 & 12,3 & 21,4 & 3,9 & 17,8 & 9,0 & 100 \\
\hline Belçika & 20,7 & 10,0 & 20,5 & 2,0 & 15,9 & 2,4 & 13,0 & 15,7 & 100 \\
\hline Danimarka & 4,1 & 0,4 & 13,1 & 16,5 & 57,2 & 0,9 & 4,2 & 3,6 & 100 \\
\hline Fransa & 36,2 & 2,3 & 16,4 & 0,7 & 9,9 & 6,2 & 10,3 & 18,0 & 100 \\
\hline Hollanda & 9,4 & 3,4 & 17,9 & 2,6 & 22,6 & 20,0 & 6,7 & 17,4 & 100 \\
\hline İngiltere & 4,0 & 12,3 & 28,7 & 0,0 & 32,5 & 5,4 & 4,9 & 12,2 & 100 \\
\hline İrlanda & 2,3 & 1,8 & 11,3 & 45,5 & 5,2 & 14,9 & 11,3 & 7,8 & 100 \\
\hline İspanya & 25,3 & 5,7 & 25,8 & 4,2 & 3,9 & 6,5 & 18,2 & 10,5 & 100 \\
\hline İsveç & 12,0 & 1,0 & 21,0 & 25,6 & 27,6 & 2,9 & 5,5 & 4,3 & 100 \\
\hline Lüksemburg & 19,5 & 1,7 & 16,1 & 0,9 & 4,6 & 9,1 & 21,0 & 27,1 & 100 \\
\hline
\end{tabular}

${ }^{\prime}$ Federal devletlerde orta düzey harcamalarını kapsamamakta, sadece alt düzey yerel yönetim harcamalarını kapsamaktadir.

${ }^{2}$ Avusturya, Belçika, Danimarka, Fransa, Lüksemburg, İspanya ve İsveç'de "ekonomik hizmet" niteliğindedir. Kaynak: OECD, (Rapport İ. Joumard/ P.M. Kongsrud., 2003'den alınarak yeniden düzenlenmişstir.

\section{Avrupa Birliği Ülkelerinde Yerel Yönetimlerin Gelir Yapısı}

Avrupa Birliği alanı içinde son zamanlarda gözlenen ve yerellik ilkesinin verdiği ivme ile yerinden yönetime ilişkin yeniden yapılanmaları, son yıllarda yerel yönetimlerin sorumluluk alanlarını arttırmakta ve buna bağlı olarak da kaynak yapısını değiştirmektedir. Birlik ülkelerinin üçte ikisinin federal yapıda olması veya üniter olmakla birlikte geniş özerkliklere sahip yerel birimlerden oluşması yerel yönetimlerin mali yapısında bir ölçüde hissedilmektedir. Öte yandan bu durum başlı başına bir uluslararası karşılaştırma yapmayı güçleştirmekte; farklı ülkelerdeki yerel birimlere ilişkin farklı tanımlamalar, kategoriler, farklı özerklik dereceleri ve farklı mali kaynak paylaşım yöntemleri nedeniyle mümkün görünmemektedir. 
Bütçe ve ekonomi yönetimine ilişkin 1992 tarihli Maastricht kriterleri ile 1997 tarihli İstikrar ve Büyüme Paktından ${ }^{21}$ kaynaklanan mali sınırlamalar, merkezi yönetimin borçlanmaları ve bütçe açıklarının yanı sıra yerel yönetimler açısından da geçerlilik göstermektedir. Bu durum yerel yönetimlerin özellikle borçlanma açısından şişkinlik gösterdiği ülkelerde yerel mali disiplin oluşturulmasını zorunlu kılmaktadır. Nitekim son dönemlerde pek çok ülkede gördüğümüz yerel yönetimlerin özkaynaklar sistemini geliştirme yönünde reform niteliği taşıyan düzenlemelerde bu zorunluluğun rolü olduğu açiktır.

Öte yandan, Belçika, İtalya ve İspanya gibi bazı ülkelerde yerel birimlerin artan mali özerklik taleplerinin bir bölümünün sebebi mali kaynak sorununun mali denkleştirme mekanizmaları boyutunu ortaya koymaktadır. Daha çok ülke içindeki ekonomik gelişmişlik farklılıklarının tetiklediği bir "zengin bölge- daha az zengin bölge" ayırımı ile gelişmiş bölgelerin merkezi devletten özerklik taleplerindeki artış mali denkleştirme mekanizmaları üzerindeki tartışmalara koşut gitmektedir. $\mathrm{Bu}$ nedenle Birliğin ekonomik ve sosyal yakınlaştırma politikalarının öneminin bir kez daha altını çizmekte yarar görülmektedir.

Bir yerel birimin özerkliği, bulundukları yerin yerel ihtiyaçlarını kendi organları eliyle yerine getirmesini ve bunun için gerekli kaynaklara sahip olmasını gerektirir. Demokrasilerin gereği olarak görülen yerel özerklik idari ve siyasi anlamı dışında mali boyutuyla konumuz kapsamına girdiğinden kısaca mali özerklik kavramının üzerinde durmak gerekecektir. 1985 yılında Avrupa Konseyi nezdinde kabul edilen Yerel Yönetimler Özerklik Şartı22 3üncü

21 JOCE C 236 du 2/8/1997.

22 Yerel yönetimler Özerklik Şartının, imzalayan ülkelerden yerel yönetimleri zaten büyük ölçüde mali özerkliğe sahip olan Batı Avrupa ülkelerine kıyasla, demokratik ve mali açıdan daha az gelişmiş yerel yönetimleri olan Doğu Avrupa ülkelerine fayda sağlayacağı düşünülmektedir. Ancak Şart, Şartı imzalayan Avrupa Konseyi üyesi ülkelerinin hemen tümünü kapsamına alması ve yerel özerkliğe ilişkin genel ilkeleri çizmesi sebebiyle anlaşma bu çalışmada özerklik tanımı için ele alınmıştır ve mali özerklik için hukuki bir dayanak olarak değerlendirilebilir. Öte yandan bazı Batı Avrupa ülkelerinin Şartı imzalamış olmakla birlikte iç hukuk sisteminden geçirmemiş olması ise gözden kaçmamalıdır. Bunlardan Fransa, Şartı 1985 yılında imzalamış olmakla birlikte Danıştay'ın (Conseil d'Etat) Fransız yerel yönetim yapısına aykırı bulduğu pek çok hükmü içermesi nedeniyle yirmi yılı aşkın bir süredir parlamentoda bekletilmiştir. Geçen zaman içinde yerel yönetim yapısında gerçekleştirilen yerinden yönetim reformları sonucu Şart yeniden parlamento gündemine gelmiş ve ancak Ocak 2006'da Senato tarafından onaylanmıştır ve parlamento sürecinin tamamlanmasını beklemektedir. 
- Ankara Üniversitesi SBF Dergisi • 63-1

maddesinde yerel özerkliği yerel yönetimlerin, kanunlar çerçevesinde, kendi sorumlulukları dahilindeki ve yöre halkının yararına kamusal faaliyetlerinin önemli bir bölümünü düzenleme ve yönetme hakkı olarak tanımlamıştır. En basit ve geniş tanımıyla idari yerinden yönetim birimleri olan yerel yönetimlerin harcamalar ve bu harcamaları finanse edecek kaynaklar konusunda sahip oldukları serbestliği anlatmakta olan mali özerklik ise kavramsal içeriği yönünden pek çoklarınca farklı şekillerde ve farklı derecelerde tanımlanmaktadır. Mali özerklik yerel yönetimlerin sadece gelir kaynaklarına karar verme ve bunları tahsil etme serbestliğini içermemektedir. Aynı zamanda kaynakları diledikleri harcamalara yönlendirmeyi, ihtiyaç duyulduğunda borçlanma yoluna başvurup, borç seviyesine ve borçlanmanın niteliğine karar vermeyi, kullanıcıları tarafindan finanse edilen bazı yerel yönetim hizmetleri için fiyat tarifelerini belirlemeyi, serbestçe bir taşınmaz mal varlığı politikası izlemeyi, bütçe ve nakit yönetimini de içermektedir. Anayasal güvence altında yerel yönetim birimin karar verici organlarının demokratik temsile dayalı olması yani yerel kamu hizmetlerinin kullanıcıları olan seçmenler tarafindan seçilmiş olması ön koşuluna bağlamaktadır. Ancak tam bağımsızlıktan farklı olarak yerel yönetimlerin merkezi idarenin ya da bir üst yerel yönetim biriminin denetiminde (vesayet denetimi) olması genel bir maliye ve ekonomi politikası izlemeyi, uygulanan politikalar arasında koordinasyon sağlamayı ve yerel yönetimlerin tümüne kamu hizmeti sunumunu sağlamaktadır.

Öte yandan mali özerkliğin yerel yönetimler yönünden harcama ve kaynak sorumluluğu yaratması, yerel halk tercihlerinin daha az maliyetle daha iyi yansıtılması ve yerel üretim koşullarına uygun hizmet sunumu sağlaması gibi ekonomik avantajlar yaratması hizmet etkinliği için önem taşımaktadır. Bu nedenle yerel yönetimlerin mali özerkliğini sağlamaya yönelik olarak Yerel Yönetimler Özerklik Şartı belli başlı mali koşulları içermektedir. Şarta göre; yerel yönetimlere Anayasa veya kanunlarda gösterilen görev ve yetkileri ile orantılı mali kaynak sağlanmalı ve yerel yönetimler bu kaynakları ulusal ekonomi politikası çerçevesinde serbestçe kullanma hakkına sahip olmalıdır. Yerel yönetimlere sağlanan mali kaynaklardan en azından bir bölümü, alt ve üst sınırları kanunlarda belirtilmiş olan ve yerel yönetimlerin bu sınırlar içinde oranlarını serbestçe belirleyebildikleri vergi, resim ve harçlardan oluşmalıdır. Yerel yönetimlerin kaynak yapıları bunların zaman içinde görev ve yetkileri

Yerel Yönetimler Özerklik Şartı maddeleri için bkz. Conseil de l'Europe, Charte Européenne de l'Autonomie Locale, 15/10/1985, Strasbourg, http://conventions. coe.int/Treaty/fr/Treaties/Html/122.htm. (10/3/2005) 
artıp geliştikçe bu gelişmeleri izleyebilecek ölçüde esnek ve çeşitli olmalıdır. Zayıf mali yapıdaki yerel yönetimler için mali denkleştirme mekanizmaları öngörülerek adaletsiz kaynak dağılımı sorunu giderilmeli ancak bu mekanizmalar yoluyla yerel yönetimlerin kendi sorumluluk alanlarında sahip oldukları seçme serbestisi sınırlandırılmamalıdır. Ayrıca yine Şarta göre, yeniden kaynak dağılımı yöntemleri ile ilgili olarak yerel yönetimlere danışılması konusu da önem taşımaktadır. Yerel yönetimlere merkezi yönetim tarafından yapılan transferler belirli projelerin finansmanı için kullandırılmamalıdır ve kendi yetki alanlarında temel özgürlüklerini kısıtlayıcı ve serbest karar almalarını engelleyici nitelik taşımamalıdır. Yatırım harcamalarını finanse etmek için yerel yönetimler kanunlar çerçevesinde olmak üzere serbestçe sermaye piyasalarından kaynak temin edebilmelidirler.

Uluslararası anlaşmalar veya Birlik içinde belirlenmiş ilkeler, Avrupa ülkelerinde yerel yönetimlerin ne kendileri ne de mali yapılarıyla ilgili heterojenliği ortadan kaldırmamaktadır. Her ülkenin kendi sosyal, ekonomik, tarihi, kültürel, hukuki ve siyasi süreçlerden ileri gelmekte olan yerel yönetim dokusunu koruması doğaldır. Avrupa ülkelerinde yerel yöneticilerin mali özerklik algılamaları üzerine yapılan bir araştırmaya göre, mali özerklik İngiltere'de yerel yöneticilerin yerel halkın taleplerini karşılayabilme yetisi olarak tanımlanırken daha çok yerel hizmetlere ve dolaylı olarak da yerel harcamalara odaklanmaktadır. Fransa'da ise mali özerklik algılaması genellikle vergi özerkliğini içermektedir ve yerel yönetimlere bırakılan vergi kaynaklı gelirlerin kapsam veya en azından oranlarına merkezi yönetim yerine yerel yönetimlerin kendilerinin karar vermesi anlamına gelmektedir. Almanya'da ise mali özerklik yerel yönetimlerin kendi gelecekleri üzerinde egemenlik hakkı oluşturabilme yeteneği olarak tanımlanırken mali özerkliğin ötesinde geniş bir özerklik anlayışının altı çizilmektedir. İspanya ve Belçika'da ise yerel yönetimlere bırakılan vergilerin kendilerinin değil ama verimliliklerinin yerel mali özerklik için daha belirleyici olduğu düşünülmektedir. Bu düşünceye göre merkezi devletten elde edilen genel bir transfer dağıtımı ve kullanımı konusunda tam yetkili olan bir yerel yönetim birimi için mali özerklik sağlayabilmektedir (Frizon, 2002: 7-8).

Birlik ülkelerinde, yerel yönetimlerin karşılaştırmalı mali özerklik analizini yaparken bu ülkeleri devlet yönetim biçimlerinden bağımsız olmak üzere, özerklik derecelerine göre dört kategoride incelemek mümkün görünmektedir (Frizon, 2002: 7-8). Bu ayırım vergi özerkliğinin yanı sıra yerel yönetimlerin harcamalarının merkezi yönetimin zorunlu tuttuğu harcamalar ve bağımsız olarak yapılan harcamalar yapma yetkisi de göz önünde tutmaktadır. Buna göre yerel yönetimlerin yaptığı harcamaların ağırlıklı olarak zorunlu harcamalardan oluşması ve bu harcamaların da büyük ölçüde merkezi devlet 
(ya da federal sistemde federe devletler) tarafından sağlanan ve yerel yönetimin az ya da hiç söz sahibi olmadığı kaynaklarla finanse edilmesi durumunda "mali yetki genişliği" (déconcentration financière) söz konusudur. Alman ${ }^{23}$ ve İngiliz yerel yönetimleri için bu durum geçerlidir. Belçika ve Fransa'da karşılaşılan "mali yerinden yönetim" (décentralisation financière) ya da vergi özerkliği durumunda yerel yönetimler harcamalarının önemli bir kısmını merkezi yönetimin zorunlu tuttuğu harcamalar oluşturmakla birlikte bu harcamaların finansmanında kullanılan kaynakları belirleme konusunda geniş bir yetkiye sahip olmaları durumunu anlatmaktadır. "Tam bütçe özerkliği" (autonomie budgétaire complète) yerel yönetimlerin harcamaları konusundaki serbestliğine karşılık kaynaklarının büyük ölçüde merkezi yönetim tarafından sağlanması durumunu ifade eder. Son olarak "tam mali özerklik" (autonomie financière complète), İspanya'nın özerk Bask ve Navarra bölgeleri örneğinde görüldüğü üzere, hem harcamalar hem de kaynaklar konusunda yerel yönetimlerin büyük ölçüde serbest ve merkezi yönetimden bağımsız olması durumunda söz konusudur (Frizon, 2002: 7-8).

Karşılaştırmalı bir analize daha uygun olması sebebiyle Avrupa Birliğine üye devletler yerel yönetimleri gelir yapıları ile incelenirken bunları üç kategoriye ayırmak mümkündür:
Yerel yönetimlere merkezi yönetimden yapllan mali transferler
Yerel yönetimlerin özkaynakları
Yerel yönetimlerin borçlanma yolu ile banka ve sermaye piyasasından kaynak yaratması

23 Alman yerel yönetimleri genellikle sahip oldukları mali kaynakların genişliği ve yetki alanlarına bırakılan faaliyetlerin çeşitliliği ile ilk bakışta özerklik yönünden diğer ülkelere göre avantajlı görünmektedirler. Ancak özerklik tanımı sadece geniş gelir kaynaklarına sahip olmakla kalmayıp, gerektiğinde bunlar üzerinde değişiklik yapma yetkisini de içermekte olduğundan Almanya'daki mali özerklik ülke içinde zaman zaman eleştirilere konu olmakta ve mali özerklik derecesi "zayıf" olarak nitelendirilmektedir. Gelir kaynakları üst yönetim birimleri olan Bund (merkezi yönetim) ve Land (eyaletler)'lerin yetki alanına bırakılmıştır. Özellikle başında doğrudan halk tarafından seçilen bir meclisi ve başkanı olan, aynı zamanda hem bir yerel yönetim birimi hem de Land'ların yetki genişliği ilkesi gereği temsilcisi durumundaki Kreise olarak nitelendirilen yerel yönetim birimleri için bu durum daha çarpıcıdır ve eleştirilerin büyük çoğunluğu bunlara yönelik olarak yapılmaktadır. Kreise'ler önemsiz sayılabilecek bazı özkaynaklara sahiptirler ve bunlarla ilgili düzenleme yapma ve oran değiştirme yetkileri bulunmamaktadır. Kreise'lerin toplam gelirleri içinde öz kaynaklarının oranı sadece \% 1 düzeyindedir. Bkz. Marand- et al., (2002: 9-10). 
Bu kaynaklar içinde yerel yönetimlerin özkaynakları özellikle de vergisel nitelikli olanları söz konusu ise mali özerklik açısından genellikle olumlu değerlendirilmektedir. Yerel yönetimlerin matrah ve oranlarına kendilerinin karar verdikleri vergilere sahip olmalarının ötesinde bu vergilerin verimliliği ve yerel harcamaları finanse etme derecesi de önem taşıyacaktır. Öte yandan merkezi yönetimden yapılan transferler genel nitelikli ve ön şartsız olduğu ölçüde mali özerklikle bağdaşır görünmektedir. Borçlanma yolu ise yerel birimler için olağan bir kaynak yolu olmayıp, tüm gelişmiş ülkelerde yatırımların finansmanında kullanılmaktadır. Ancak yerel yönetimler için belirli ön koşullara bağlanmayıp istedikleri mali kuruştan istedikleri miktarda ve oranda borçlanabildikleri ölçüde "kullanım kolaylığı" ve esnekliği yaratmakta (Jossa/Semo, 1990: 122) ve bu nedenle de mali özerklikle bağdaşır görünebilmektedir.

\section{Yerel Yönetimlere Merkezi Yönetimden Yapılan Mali Transferler}

Hemen her ülkede mevcut bu sistem bütçe kaynaklı merkezi devlet veya federe devlet transferlerinden oluşmaktadır. Yerel yönetimlere yapılan mali transferler çok değişik biçimlerde olabilir. Örneğin, genel veya özel amaçlı yardımlar, hibeler, sübvansiyonlar, merkezi yönetim toplam vergi gelirlerinden pay verme gibi nakdi transferler yanında, kredi garantisi biçiminde de olabilir.

Yerel yönetimler arasındaki eşitsizlikleri giderme, yönetim düzeyleri arasında mali dayanışma yaratma ve denkleștirme ihtiyaçları ve yerel yönetimlerin artan harcama eğilimlerine uyum sağlayamayan gelir kaynakları sebebiyle başvurulan mali transferler yönteminin önemi kamu maliyesi için giderek artmaktadır ${ }^{24}$. Yerel yönetimler için bu kaynağın az çok öngörülebilir ve maliyetsiz olması önemli bir avantaj yaratırken, artan harcama ihtiyaçları nedeniyle merkezi devlet bütçesi için baskı unsuru yaratma dezavantajını taşımaktadır.

Bir genellemede bulunulduğunda bir ülkede mali transferlerin yerel yönetim bütçeleri içindeki payı çok yüksek olduğunda, öz kaynaklar sisteminin daha az önemli ya da zayıf olduğu görülmektedir. Ancak devlet yönetim biçiminin transferlerin büyüklüğüyle doğrudan ilgili olduğu saptanması çok doğru gözükmemektedir. Dolayısıyla devletin üniter ya da federal olması ile

24 Yerel yönetimlere devlet tarafından yapılan mali yardımların gerekçeleri ve biçimleri için bkz Ülkmen (1960: 160-177), Nadaroğlu (1998: 93-98), Shoup (1969: 620631). 
Ankara Üniversitesi SBF Dergisi • 63-1

yapılan mali transferlerin büyüklüğü birbirinden bağımsız görünmektedir. Ancak göreli önemi ne olursa olsun hemen her ülkede yerel yönetimlere, değiş̧ik biçimler ve nitelemelerle, mali transfer sistemi ile merkezi yönetimden kaynak aktarımı yapılmaktadır. Merkezi yönetimden yapılan transferlerde mali özerklik derecesini belirleyen ise yerel yönetimin bu kaynağa doğrudan sahip olup olmaması, transferin şarta bağlı olup olmaması veya belli bir faaliyet türü için ya da genel harcamalar için verilip verilmemesi gibi unsurlarla belirlenmektedir. Öte yandan yerel yönetimler için yerel vergilerle güçlü bir özkaynak sistemi geliştirilmesi durumunda, merkezi yönetimden yapılan mali transferlerin genel olarak yerel birimlerin bazı harcamalarını denetim altına almak ve belirli harcamalara teşvik etmek için yapıldığı görülmektedir ${ }^{25}$. Transferlerin özel amaçlı yardımlar biçiminde olmasında ise merkezi yönetimin yetki devri ile kamu hizmeti sağlama, temel kamu hizmetlerinde asgari standartlar oluşturma ve yerel yönetimler arası eşitsizlikleri giderme amaçlarının baskın olduğu görülmektedir. Eşitsizlik giderme ve mali dayanışma mekanizmaları söz konusu olduğunda önceliklere göre belirlenen kriterler temeline göre yerel yönetimlere fon transferi gerçekleştirilmektedir.

Borçlanma dışı olağan yerel yönetim gelirleri içinde transferlerin oranına baktığımızda Avrupa Birliği ortalaması \% 40 civarındadır. Buna göre Almanya (\% 55), Belçika (\% 46), İspanya (\% 59), Yunanistan (\% 60), İtalya (\% 65), Portekiz (\% 49) ve Hollanda (\% 62) ortalamanın üstündedir. Yerel yönetimleri geleneksel olarak vergilerle finanse edilen Kuzey Avrupa ülkelerinde ise ortalamanın oldukça altında bir oran gerçekleşmektedir (Danimarka \% 18, İsveç \% 13 ve Finlandiya \% 23) (Dexia, 2003: 12).

$\mathrm{Bu}$ transferlere kaynak oluşturma bakımından da Birlik üyelerinde heterojen bir yapı bulunmaktadır Örneğin, İrlanda genel bir yerel yönetimler fonunu transferin kaynağ 1 olarak kullanmaktadır. $\mathrm{Bu}$ fon, otomobil kullanma vergisi ile Maliye Bakanlığından bu fon için ayrılan ödenekten oluşmaktadır. Lüksemburg'da ise genel bütçe vergi gelirlerinin bazı kalemlerinden (gelir vergisinin \% 8'i, katma değer vergisinin \% 10'u ve taşıt vergisinin \% 20'si) alınan payla oluşturulan Mali Yardım Yerel Yönetimler Fonundan yerel birimlere transfer yapılmaktadır. Bütçeden gelen bu genel nitelikli kaynaklar genelde yerel yönetimlerin yatırım harcamalarını finanse etmektedirler. $\mathrm{Bu}$ durum Belçika, Danimarka ve İspanya, Fransa, Finlandiya, İngiltere ve İsveç için de geçerlidir.

25 OECD (1994: 13). Ancak sadece mali kaygıların harcama denetimi yaratmayacağı da açıktır, bunun yanı sıra anayasal ve hukuki gerekçelere de dayalı olarak sinırlandırılabilmektedir. 
Yerel yönetimlere yapılan transfer sistemi genellikle bölgesel eşitsizlikleri giderme aracı olarak kullanılmaktadır (Joumard/Kongsrud, 2003: 178). Mali denkleştirmeye dayalı transfer sistemi Avrupa Birliği ülkelerinde genellikle iki biçimde görülmektedir. Birinci yöntemde kaynakları fazla ve harcamaları az yerel birimlerden kaynakları yetersiz, harcamaları fazla yerel birimlere aktarma söz konusudur. Bu yöntem daha çok Kuzey Avrupa ülkelerinde görülmektedir. İkinci yöntem, kaynakları yetersiz yerel birimlere diğerlerine kıyasla daha fazla olmak üzere merkezi yönetim transferleridir. Bu yöntem hem birimler arası dikey ve yatay eşitsizlikleri gidermek üzere kullanılmaktadır. Federal yapıdaki ülkelerde ikili veya üçlü düzeyde gerçekleştirilen yeniden dağıtım amaçlı transfer mekanizmaları bulunmaktadır. Örneğin güçlü bir mali denkleştirme mekanizmasına sahip Almanya'da her iki yöntemin de uygulandığı görülmektedir. Federal düzeyde Länder'ler arasında ve Länder düzeyinde de belediyeler arasında adaletli gelir bölüşümüne yönelik transfer sistemi bulunmaktadır. Bu sistemin en önemli unsuru olan katma değer vergisi hasılatı her üç yönetim düzeyinde paylaşılmakla birlikte ayrıca Länder'lerin payının \% 75'i da nüfusa ve \% 25'i de mali kapasiteye göre kendi aralarında yeniden dağıtıma konu olmaktadır. Öte yandan mali kapasitesi ortalamanın üstünde olan Länder'lerden mali kapasitesi ortalamanın altında olanlara yapılan transfer sistemi ("Finanzausgleich") aynı zamanda federal devletten Länder'lere yapılan denkleştirme yardımı ile desteklenmektedir (Marand, 2002: 7-8). İspanya'da ise üçlü transfer sistemi ile özerk topluluklara mali destek olunmaktadır. İlki her özerk topluluk için yıllık olarak hesap edilen ve toplulukların eğitim faaliyeti gerçekleştirip gerçekleştirmediğine göre değișen bir genel transfer sistemidir (PIE). Ayrıca kişi başına ortalama gelirleri ülke ortalamasının altında kalan özerk topluluklara yatırım harcamaları için yapılan transferler ve yalnızca belirli şartları sağlayan özerk topluluklara yapılan bir transfer sistemi daha bulunmaktadır. Çeşitlendirilmemiş ve tekdüze bir yerel vergi sistemine sahip İngiltere'de ise sistematik biçimde her yıl merkezi yönetim tarafindan hesaplanan yerel yönetimlerin teorik harcama seviyelerinin ("total standard spending") yerel vergilerden arta kalan kısmının finansman1, genel bir transferin ("revenue support grant") yanı sıra eğitim ve güvenlik harcamalarına yönelik özel amaçlı yardımlarla sağlanmaktadır (Byrne, 1994: 307-316).

Yerel yönetim finansmanı büyük ölçüde transferlere dayalı olan Hollanda tipik bir örnek oluşturmaktadır. İl yönetimlerinin bütçe gelirlerinin \% 90'1 ve belediye yönetimlerinin \% 85'i merkezi devlet transferlerinden oluşmaktadır. Genel amaçlı yardım niteliğindeki transferler yerel yönetimler arası eşitsizliği gidermek üzere il yönetimi ve belediye yönetimleri için ayrı ayrı olmak üzere fonlar yoluyla gerçekleştirilmektedir. Bu fonlardan değişik kriterlere göre yerel 
yönetimlere dağıtım yapılmaktadır. Transferlerin yaklaşık olarak \% 60'ını oluşturan özel amaçlı transferler nedeniyle yerel yönetimler arası eşitliği sağlama mekanizması bu ülkede merkezileştirilmiş durumdadır ${ }^{26}$.

\section{Yerel Yönetimlerin Özkaynakları}

$\mathrm{Bu}$ tip yerel yönetim gelirleri bunlara önemli mali özerklik sağlama avantajına sahiptir. Özellikle de vergi özerkliği anlamında kendi vergi gelirlerini ve bunların oranlarını belirleme konusunda serbestliğe sahip oldukları ölçüde önem taşır. Ancak eşitsizlik yaratma, fakir belediyeler aleyhine ekonomik ayırımcılığa neden olma, ulusal mali düzenlemeler yapmayı zorlaştırma gibi çeşitli olumsuz yönleri nedeniyle de eleştirilmektedir. Yerel birimlerin yerel hizmetleri ve ihtiyaçları ile bunlar için kullanılacak kaynakları doğrudan doğruya karşı karşıya getirmektedir. Matrah değişikliğini izleme, borç geri ödeme, projelere tam ya da kısmı oto-finansman sağlayarak yatırıma dönüştürme gibi etkileri nedeniyle ise pek çok yerel birim için önemli bir gelir çeșididir.

Tablo II AB Ülkelerinde Yerel Yönetim Öz Kaynakları

\begin{tabular}{|l|c|c|c|c|}
\hline \multirow{2}{*}{} & \multicolumn{2}{|c|}{$\begin{array}{c}\text { Toplam Kamu Gelirlerindeki } \\
\text { Payı }^{\mathbf{1}}\end{array}$} & \multicolumn{2}{c|}{$\begin{array}{c}\text { Toplam Vergi Gelirleri } \\
\text { İçindeki Payı }\end{array}$} \\
\cline { 2 - 5 } & $\mathbf{1 9 8 5}$ & $\mathbf{2 0 0 1}$ & $\mathbf{1 9 8 5}$ & $\mathbf{2 0 0 1}$ \\
\hline Almanya & 31,9 & 32,4 & 30,8 & 29,2 \\
\hline Avusturya & 24,6 & 21,4 & 23,8 & 18,9 \\
\hline Belçika & 11,4 & 11,3 & 4,8 & 28,6 \\
\hline Danimarka & 32,3 & 34,6 & 28,4 & 33,8 \\
\hline Finlandiya & 24,8 & 24,7 & 22,4 & 22,4 \\
\hline Fransa & 11,6 & 13,1 & 8,7 & 9,3 \\
\hline
\end{tabular}

26 İller fonundan dağıtım 1/3 kuralına göre yapılmaktadır: fonun 1/3'ü tüm illere götürü ve eşit olarak, 1/3'ü nüfusa göre ve kalan 1/3'ü de yüzölçümüne göre dağıtılmaktadır. Belediyeler fonu ise nüfus, konut sayısı, yüzölçümü, sosyo-ekonomik yapı ve vergi ödeme kapasitesine göre dağıtılmaktadır. CES (2001: II-77).

$\mathrm{Bu}$ durumda fonlardan yapılan transferlerin götürü bölümlerinin eşitsizlik giderme fonksiyonun olmadığını, değişik krtiterlere göre yapılan dağıtımın ise merkezi devletin belirlediği önceliklere yönelik bir düzeltme yaptı̆̆ını söylemek mümkündür. 


\begin{tabular}{|l|c|c|c|c|}
\hline Hollanda & 11,4 & 11,1 & 2,4 & 3,5 \\
\hline İngiltere & 10,5 & 7,6 & 10,2 & 4,1 \\
\hline İrlanda & 32,3 & 34,6 & 2,3 & 1,9 \\
\hline İspanya & 17,0 & 20,3 & 11,2 & 16,5 \\
\hline İsveç & 34,3 & 32,0 & 30,4 & 30,8 \\
\hline İtalya & 10,7 & 17,6 & 2,3 & 12,2 \\
\hline Lüksemburg & 8,0 & 7,4 & 6,6 & 5,6 \\
\hline Portekiz & 7,6 & 8,3 & 3,5 & 6,5 \\
\hline Yunanistan & 3,7 & 3,7 & 1,3 & 1,0 \\
\hline AB(15)Ortalaması & 18,14 & 18,67 & 12,61 & 14,95 \\
\hline
\end{tabular}

${ }^{I}$ Merkezi yönetimden mali transferler dıșarıda ancak yönetimler arası vergi paylaşma anlaşmaları dahil olmak üzere.

${ }^{2} Y$ önetimler arası vergi paylaşma anlaşmaları dahil olmak üzere Kaynak: OECD, (Rapport I. Joumard/ PM Kongsrud,).

Tablo II'de görüldüğü gibi, Birlik ülkeleri 1985 ve 2001 yıllarına göre sahip oldukları özkaynaklar yönünden incelendiğinde, 2001 yılında toplam kamu gelirleri içinde özkaynakların payının çok fazla değişmediği görülmektedir. Ancak yerel yönetimlerin özkaynaklarının üye ülkelerdeki toplam vergi gelirlerine oranın 1985'teki \% 12,61'e karş1lık 2001'de \% 14,65 olarak gerçekleşmesi özellikle İspanya, İtalya, Belçika ve Portekiz'de meydana gelen yerel yönetim reformlarıyla açılanabilir. Özellikle İtalya'da bu dönemde gözlenen kayda değer artış 1997 ve 2001 yılında gerçekleştirilen reformların yarattığ 1 etkiden kaynaklanmaktadır ${ }^{27}$. İngiltere için tersi bir durum

271997 yılında "Bassani Yasası" ve 2001 yılında "Amato Yasası" sonucu yeniden yapılandırılan yerinden yönetim mekanizması ile yerel yönetimlere daha fazla özerklik tanınmıştır. 2001 yılında gerçekleştirilen Anayasa değişikliği ile "...belediye, il, büyükşehir ve bölge yönetimlerine özerk kaynaklara sahiptirler. Bunlar Anayasal ilkeler çerçevesinde ve kamu maliyesi ve vergi ilkelerine uyumlu olarak vergi tarh ve tahsilatına yönelik kendi rejimlerini belirleme ve uygulama hakkına sahiptirler" (Anayasa md 119/2). Mali anlamda ise bu değişiklik 1997'ye kadar merkezi yönetimden transfer esasına dayanan yerel yönetimlerin bu tarihten sonra kaynaklarının \% 45'inin vergi öz kaynaklarına dayanması anlamanı taşımaktadır. Amato Yasası ile bölgelere kendi vergilerini koyma yetkisi ile bölgede elde edilen KDV hasılatından pay verilmektedir. 
görülmektedir. 1985 yılına göre 2001 yılında yerel yönetimlerin özkaynaklarının hem toplam kamu gelirleri içindeki payı hem de toplam vergi gelirleri içindeki payında azalma görünmektedir. Geleneksel olarak İngiltere'de yerel yönetimlerin harcamaları için vergi kaynaklı gelir kullanmak yerine merkezi yönetimden transferler yolunu tercih ettiği görülmektedir (Darby vd., 2002: 9). Nitekim yerel birimlerin oranını kendi tespit ettikleri 28 tek vergi olan emlak vergisi niteliğindeki "council tax" 29 ile oranı ve tahsilatı merkezi devletin yetki alanında kalan ve yerel yönetimlere dağıtımını objektif kriterlere göre yine merkezi yönetimin yaptığı işletme vergisi "business tax" dışında vergi kaynaklı gelirleri bulunmamaktadır.

Kuzey Avrupa (Danimarka, İsveç ve Finlandiya) ülkelerinde vergi gelirlerinin toplam yerel yönetim gelirlerine oranı Avrupa Birliği ortalamasının üzerindedir. Bu ülkeleri 1993 yılında federal bir yapıya kavuşan Belçika ile Almanya izlemektedir. Belçika'da yerel yönetimler, yaratılmalarından tahsilatına kadar tüm vergileme süreçlerinde tek yetkili oldukları yerel vergilere ve bazı ulusal vergilere ek oran eklemek şeklinde yaratılan vergi kaynaklarına sahiptir. Birinci grup vergi gelirleri ${ }^{30}$ çok verimli olmamakla birlikte belediyelerin toplam vergi gelirlerinin \% 18'ini sağlamaktadır. İkinci grup vergi kaynakları ise emlak vergisi, gelir vergisi ve otomobil dolaşım vergisi üzerinden yerel yönetimler için ek vergi koymak suretiyle kaynak yaratmaktadır. Bunlar içinde emlak vergisine eklenen oran ile yerel yönetimler toplam vergi gelirlerinin \% 43,3'ünü sağlamaktadırlar (MARAND vd., 2002: 8). Almanya'da da benzer şekilde belediye vergileri yerel harcamaların

İtalyan Anayasası için bkz. http://www.oefre.unibe.ch/law/icl/it00000_html $(25 / 5 / 2006)$

28 Türkiye'de uygulanan emlak vergisinde olduğu gibi, 1998 yılına kadar "council tax" için merkezi devletin belirlediği üst sınırı aşmamak üzere yerel yönetimler bu verginin oranını belirleyebiliyordu. Ancak bu göreceli serbestlik merkezi yönetimin bu oranı çok aşağıda tutması sebebiyle uygulamada çok anlamlı değildi. Bu tarihten sonra merkezi devlet üst sınır koymamak ancak gerekli bulduğunda yerel yönetimlerin belirledikleri orana müdahale edebilmektedir. Müdahale genelde vergi oranının aşırı arttığı durumlarda yapılmaktadır.

29 Coucil tax'dan önce 1990 yılında yapılan bir reformla bir Ortaçağ vergisi olan ve 1925 y1lında birleştirilerek tek oranlı uygulanan "rates"lerin yerini “community charge" veya "poll tax" olarak adlandırılan vergi getirilmiştir. Ancak baş vergisi niteliği nedeniyle karşılaştığı kamuoyu direnci sonrası 1993 yılında yerini council tax'e birakmıştır.

30 Büro vergisi, motor gücü vergisi, bilgi-işlem araçları vergisi, eğlence ve gösteri vergisi, park vergisi ve köpek vergisi gibi hasılatı sınırlı çok çeşitli vergilerden oluşmaktadır. 
finansmanı için önemli bir kaynak konumundadır. Komün belediyeleri için oranlarını belirledikleri emlak ve işletme vergileri en önemli kaynaklardandır. 1998 yılında gerçekleştirilen bir reformla "ticari ve sınai işletme brüt sermaye vergisi" komün belediyelerinin yetki alanından alınarak yerine federal katma değer vergisinden ("Umsaztsteuer") pay verilmektedir. Öte yandan belediyeler ve Land'ler bazı "küçük vergiler" ("Bagatellesteuer") ${ }^{31}$ konusunda da yetkilendirilmiştir. Belçika ve Almanya örneklerinin yanı sıra yerel yönetimleri büyük ölçüde yerel vergilerle finanse edilen Danimarka'da 2007 yılı başından itibaren uygulanacak yeni yerel yönetim reformu ise dikkat çekici bir sonuç ortaya koymaktadır. Reform temel olarak sayıları çok fazla (271) ancak ölçekleri küçük olan belediyeleri önemli ölçüde azaltıp daha büyük ölçekli belediyeler (98) ve ilk defa oluşturulacak beş yeni bölge idaresi getirecektir. Bunların finansmanında ise ölçek ekonomilerinden faydalanmak üzere merkezi devletin vergi toplama ve dağıtma konusundaki ülke ölçeğine göre daha etkin yönetiminin kullanılması amaçlanmaktadır ${ }^{32}$.

Birlik ülkelerinde tercih edilen yerel vergilerin neler olduğuna bakıldığında ise Birlik içinde büyük bir heterojen yapı gözlenmektedir. Ancak temel olarak üç büyük vergi grubundan bahsetmek mümkündür: Emlak vergisi, gelir vergisi ve ekonomik faaliyet üzerinden alınan meslek veya işletme vergisi. Ancak bunlar dışında da Avrupa Birliği ülkelerinin geleneksel vergi yapılarına uygun yerel vergiler yelpazesine dikkat çekmek gereklidir. Harcama vergileri (özellikle içki satış ve tüketimi üzerinden alınan), servet vergileri (veraset ve intikal üzerinden alınan yerel vergi, varlık vergisi, kentsel alan gayrimenkul değer artışı üzerinden yerel vergi gibi) ve çevre ilintili vergiler (su kirletme vergisi, yakıt vergisi, motorlu taşıt vergisi, köpek vergisi, turizm vergisi, ilan vergisi gibi) bulunmaktadır.

Konusunun yerelleştirilerek bir yerel yönetim birimine aktarılması en uygun vergi olarak görülen emlak vergisi hemen tüm Birlik ülkelerinde uygulanmaktadır. Yakın zamana kadar bu vergiyi uygulamayan iki Birlik ülkesi İsveç ve İtalya da sistemlerine emlak vergisini almışlardır (CES, 2001:II-79). Yerel yönetim özerkliğinin çok önemli görüldüğü İsveç'te yerel yönetimlerin

31 Bunlar içki üzerinden alınan vergiler, köpek vergisi, eğlence vergisi, avcılık ve balıkçılık vergisi, turistik komün belediyelerinde ikinci konutlar üzerinden alınan emlak vergisi, yangın koruma katılım payı ve veraset ve intikal vergisinden yerel yönetimler için alınan ek vergiden oluşmaktadır. Ayrıntılı bilgi için bkz. Marand (2002:8-10). Ayrica bkz. Can (2004: 37-96).

32 Reformun ayrıntıları için bkz. LDK (2006)). Yeni oluşturulacak olan bölgelerin kendi yetki alanlarında vergi kaynaklı gelirleri olmayıp, bütçeden ve belediyelerden yapılan transferlerle destekleneceklerdir. 
finansmanı da temel olarak, taşınmaz (emlak ve/veya arazi) üzerinden alınan ve ödeme gücü ilkesi ile bağlantısı sinırlı ve bu nedenle düşük oranlı uygulandığından çok verimli olmayan emlak vergisi yerine, gelir vergileri yoluyla sağlanmaktadır. Bir yerel yönetime ve yerel kamu hizmetine bağlanma kolaylığına karşılık matrahını piyasa şartlarına göre güncel tutmaya ilişkin zorlukları da taşıyan emlak vergisi genellikle artan yerel kamu harcamaları için tek başına oldukça yetersiz kalmaktadır. Uygulamada vergi doğrudan doğruya taşınmazın (bina, arsa ve arazi) büyüklüğü ile orantılı olarak veya taşınmaz değeri üzerinden alınmaktadır. Taşınmaz değeri üzerinden alındığı durumlarda taşınmazın idarece veya yükümlü beyanları üzerine değerlendirilmesi gereklidir. Taşınmaz genellikle piyasa değeri (Hollanda, İngiltere, Danimarka ve Yunanistan) veya idarece hesaplanan yıllık tahmini kira değeri (Belçika, İrlanda, Portekiz, İsveç, İspanya) esas alınarak değerlemeye tabi tutulmaktadır. Ancak idarece gerçekleştirilen bu değerlemeler genellikle çok uzun sürdüğü ve masraflı olduğu için düzenli olarak yapılamadığından vergi matrahlarının aşınması sık rastlanan bir problemdir ${ }^{33}$. Öte yandan emlak vergisinin yalnızca ticari işletmelere uygulanan biçimine (İrlanda, Danimarka, Almanya, İngiltere) rastlamak da mümkündür. İngiltere örneğinde "uniform business rates" veya "non-domestic rates" adı verilen bu tür emlak vergisinde taşınmazın maliki veya kiracısı bu taşınmazda yürütülen ticari ve sınai faaliyet nedeniyle emlakin yıllık kira değeri üzerinden vergiye tabi olmaktadır. Bu verginin hasılatı bir fonda toplanarak daha sonra yerel yönetimlere yetişkin nüfusuna göre dağıtılmaktadır (Byrne, 1994: 326-337).

Gelir üzerinden alınan vergiler çok yaygın olmamakla birlikte bazı ülkelerin (Almanya Belçika, Danimarka, Finlandiya, İspanya, İsveç ve İtalya) yerel yönetimleri için önemli bir kaynak konumundadır. Emlak vergisine göre daha verimli ve kişiselleştirilebildiği için daha adil olan bu vergi aynı zamanda düzenli hasılatı ile yerel özerkliği de destekler görülmektedir. Yerel gelir vergisi ulusal gelir vergisi ile aynı matrahtan veya ödenen gelir vergisi tutarının belirli bir oranı yerel yönetimler için ayrıca alınmaktadır. Ancak gelir vergileri genellikle merkez veya üst yönetim birimi ile paylaşılan vergilerdendir. İspanya örneğinde gelir vergisinde vergilendirme yetkisi merkezi devlet ile özerk topluluklar arasında paylaşılmaktadır. Ulusal gelir vergisi tarifesinin \% 15'lik bölümünde, beş y1lda bir yapılan merkezi yönetim ve özerk bölgeler anlaşmasına göre, indirim yapılarak bu kısım bölgesel düzeyde gelir vergisi

33 Almanya'da emlak vergisi (Grundsteuer) için en son değerleme 1964'te yapılmıştır. İngiliz sisteminde ise hem council tax hem de business rates için yeniden değerleme işlemi 1990 yılından beri periyodik olarak beş yılda bir Valuation Office Agency tarafindan gerçekleştirilmektedir. MDI (2004: 2-3). 
marj1 olarak kullanılmaktadır. Ulusal vergi tarifesinde indirim yapılmadığında ise gelir vergisinin ne oranda uygulanacağ 1 konusunda önceden çizilmiş çerçeveye göre sinırlandırılmıştır ${ }^{34}$. İtalya'da ise 2000 yılında "Amato Yasası" olarak bilinen yerel vergi reformundan beri gelir vergisine ek vergi niteliğinde belediye payı alınmaktadır. Belediye gelir vergisinin merkezi yönetim tarafından belirlenen sabit oranına belirli bir sınırı aşmayan değişken bir oran eklenerek vergilendirme gerçekleştirilmektedir ${ }^{35}$.

Kurumlar vergisine temel alınan matrah üzerinden yerel yönetimler için vergi alınması da rastlanan bir durumdur. $\mathrm{Bu}$ durum Lüksemburg'da, Almanya'da, munzam vergi niteliğinde Portekiz'de, 1990'ların başına kadar da İsveç ve Danimarka'da uygulanmıştır (MDI, 2004: 3-4). Uygulamanın terk edilme sebeplerinin başında bir yandan kurum kazançlarının yerel yönetim hizmetleriyle olan bağlantısındaki göreli zayıflık, öte yandan kurum kazançlarının kaynaklarının belirli bir yerel yönetime bağlanmasındaki zorluk gelmektedir. Öte yandan kurumlar vergisi hasılatının konjonktürel dalgalanmalara bağlı olması, yerel yönetimler yönünden gelir düzensizliği yaratmakta ve yerel hizmetlerin aksamasına yol açabilmektedir.

Kurumlar vergisinin sakıncaları nedeniyle işletmeler ticari ve sınai faaliyetleri dolayısıyla meslek vergisi niteliğinde yerel vergilere de konu olabilmektedirler. Almanya, Fransa, İtalya, İspanya, Lüksemburg ve Portekiz'de uygulanmaktadır. En ilginç örneği gördüğümüz Almanya'da meslek vergisi (Gewerbesteuer) ticari ve sınai işletmelerin vergi öncesi kazançları üzerinden düzeltmeler yapılarak tarh edilmektedir. Tahsilatı belediyeler tarafindan yapılan vergi daha sonra $\% 15$ oranında Länder'lere ve $\% 5$ oranında da federal devlete aktarılmaktadır (CE, 2002: 135). Ancak hasılatının çok taraflı paylaşımının yanı

$34 \mathrm{Bu}$ sinırlandırmaya göre bölgesel gelir vergisi ulusal gelir vergisi tutarından $\% 20$ eksik ve fazla olamayacaktır.

35 İtalya'da gelir vergisine ek oran uygulama yöntemi hem belediyeler hem de bölgeler düzeyinde geçerlidir. Ek oranlar belediye ve bölgeler için ayrı ayrı belirlenmiştir. Buna göre belediye ek oranının değişken bölümü yılda $\% 0,2$ ve üç yılda da $\% 0,5$ sınırını aşmamak üzere uygulanır. Bölgeler için ise 2000 yılı için sabit \% 0,9 oranına yılda \% 0,5 değişken oran eklenerek vergileme gerçekleştirilmektedir. 1970lerden 1990ların başına kadar merkezi yönetimden doğrudan transfer sistemiyle desteklenen İtalyan yerel yönetim yapısı 1997-2001 arasında kademeli olarak yeniden şekillendirilmiş ve yerel yönetimlere (belediye ve bölge yönetimleri) vergi özerkliği sağlama ilkesine uygun olarak pek çok yerel vergi ve ek vergi sisteme sokulmuştur. Yerel vergi özerkliğinin temeli ise verimli vergilerden oluşmaktadır. Bu çerçevede bölge yönetimlerine gelir vergisinden başka katma değer vergisinden de pay ayrılmaktadır. İtalyan yerel yönetim reformunu ayrıntıları için Bkz. Communiqué CES (2001: II-83-85). 
sıra verginin bir diğer özelliği ise ticari işletme kârı ile birlikte matrahı oluşturan unsurlardan biri olan işletme aktiflerinin 2000 yllından sonra meslek vergisi matrahından çıkarılması sonucu verginin yerel bir kazanç vergisi biçimine dönüşmesidir. Meslek vergisi Fransa'da ise hasılatı yönünden oldukça önemli bir yerel vergi kaynağıdır, çünkü Fransız yerel yönetimleri vergi gelirleri toplamının \% 44'ünü sağlamaktadır. Fransa'da meslek vergisi, tarihi "patente" vergisinin revize edilmiş biçimidir. $\mathrm{Bu}$ ülkedeki uygulamasında Alman uygulamasından farklı olarak kâr yerine, işletme faaliyetlerinde kullanılan taşınmazların emlak vergisine esas olan kira değerine, duruma göre, işletme aktifinde bulunan makine ve teçhizatın veya diğer teknik ve mesleki donanımın kira değeri ve yine duruma göre işletme tarafından ödenen ücretin veya işletme gayrisafi hasılatının bir bölümü ${ }^{36}$ eklenmek üzere belirlenen bir matrah üzerinden alınır. Fransız meslek vergisi (taxe professionelle) yalnızca ticari ve sınai işletmeleri değil, ücret dışında kalan tüm mesleki faaliyetleri de kapsamına almaktadır. Oldukça karmaşık bulunan matrah belirleme yöntemi ve çok çeşitli istisna ve muafiyet uygulamalarıyla bozulan vergi adaleti yönünden tartışmalara konu olan verginin oranı her y1 yerel yönetimlerce belirlenmektedir (Bouvier, 1993: 42). İtalya'da yine 1999 yılından beri bazı önemsiz yerel vergilerin yerine "üretim faaliyeti üzerinden alınan bölgesel vergi" (IRAP) adı verilen işletme katma değeri üzerinden ticari ve sınai işletme vergisi uygulanmaktadır ${ }^{37}$. Almanya ve Fransa'dan farklı olarak işletme tarafından yaratılan amortismandan arındırılmış katma değer üzerinden, tarım ve kamu sektörünün de dahil olduğu geniş bir yükümlü grubundan alınmaktadır (CE, 2002: 261-262). Verginin oranı merkezi yönetim tarafından belirlendiği ve bu oranı bölge yönetimleri yalnızca \% 1 oranında yükseltebildiği için yerel mali özerklik yönünden tartışılmıştır. 2003 yılında ise yerel yönetimlerin ek oran belirleme yetkisine son verildiğinden hasılatı bir yerel birime aktarılan merkezi yönetim vergisi olarak kalmıştır. Matraha giren ücretler nedeniyle işgücüne olan olumsuz etkisi ve işletmelerin bu vergiden kaçınma ve kaçırmaya yönelik eğilimleri diğer eleştiri konuları olmuştur (MDI, 2004:5-6). Bu nedenle verginin uzun dönemde yürürlükten kaldırılması planlanmaktadır.

36 Fransa'nın işsizlik sorunu nedeniyle işgücünü teşvik edici politikaları sebebiyle 1999-2003 döneminde kademeli olarak ücret unsuru meslek vergisi matrahı kapsamından çıkartılmıştır.

37 Merkezi yönetim tarafindan tahsil edilip bölge yönetimine tahsis edilen vergiden 2001 y1lına kadar belediyelere pay verilmekteydi. Bu tarihten sonra pay verme yöntemine son verilerek belediyelere yapılan merkezi yönetim transfer payı arttırılmıştır. 
Özkaynakların vergi niteliğinde olanların yanı sıra kamu hizmeti karşılı̆̆ 1 kullanıcılardan alınan kullanım bedeli ile katılma paylarının bulunduğunun da altını çizmek gereklidir. Son dönemlerde merkezi ve yerel yönetimlerin vergi koyma yerine tercih ettikleri bu yöntemler popüler olmayan vergilere ve genel bütçe için önemli bir yük olan transferlere alternatif olduğu görülmektedir. Yerel yönetimler için merkezi yönetim iradesinin dışında kendilerince kontrol edilen esnek bir gelir kaynağı yarattığından günümüzde piyasa ekonomilerinde yerel özerkliğe uygun bir finans yöntemi olarak algılanmaktadır. Ancak tüm yerel kamu hizmetlerinin özellikle de sosyal nitelikli olanların tarifelendirilme ya da fiyatlandırılmaya uygun olmaması, kullanıc1 ve faydalanıcıları belirlemeye ve gelir adaletsizliğine ilişkin zorluklar, kamu hizmetlerine ulaşım ve seçim ekonomisinden kaynaklanan sebepler, fiyatlandırma yoluyla kaynak yaratmanın sınırlarını oluşturmaktadır ${ }^{38}$. Katılma paylarında kullanım bedelinden farklı olarak yerel hizmetten yararlananların bu yararlanma karşılı olarak fiyat yerine hizmetin bir kısmının finansmanını karşılayacak bir bedel ödemesi söz konusudur. Kullanım bedelleri ve katılma payları ile yerel yönetimlerin en fazla Kuzey Avrupa ülkelerinde kaynak yarattığını görülmektedir (toplam yerel kaynakların \% 15-20'si).

Yerel yönetimlerin emlak gelirlerinden (kira ve elden çıkarma) ise bu çalışma kapsamında sıralamakla yetinilecektir.

Yerel vergiler konusunda görünen dağınık yapının Birliğin vergilendirmeye ilişkin çalışmaları yönünden doğrudan bir etkisi bulunmamaktadır. Almanya gibi KDV hasılatını merkezi devletle paylaşan yerel yönetimler yönünden, verginin Birlik tarafından uyumlaştırılmış ve Birlik bütçesinin önemli bir kaynağı olması sebebiyle, aynı zamanda Birlikle de paylaşması anlamını taşımaktadır. Diğer vergiler yönünden ise ulusal olan vergilendirme yetkisi nedeniyle yerel vergilerin Birliğin doğrudan ilgi alanına girmemektedir. Ancak Maastricht kriterlerinin yarattığı mali baskı sebebiyle yerel yönetimlerin kaynak yapısının varolan vergilerle merkezi yönetim transferleri ve vergi hasılatı paylaşımına dayandığı görülmektedir.

\section{Banka ve Sermaye Piyasasından Elde Edilen Kaynak}

Genel ekonomik eğilim özellikle 1980'li yıllardan sonra banka ve sermaye piyasalarından borçlanma yoluyla kaynak yaratarak faaliyetleri finanse

38 Kamu hizmetlerinin fiyatlandırma yoluyla finansmansı konusunda ayrıntılı bilgi için bkz. R.Broadway vd.,(1994: 17-18) ve Bouvier (1993:143-146). 
etmek olarak özetlendiğinde yerel yönetimlerin de bu eğilime uygun hareket etmekte olduğu görülmektedir. Ülkelere göre bu yolla yerel yönetim faaliyetlerini finanse etme oranı ve borç yapısı değişiyor olmakla birlikte tüm yerel yönetimler için bu yöntem geçerlidir.

Borçlanmanın yerel yönetimler için yatırım faaliyetlerini uzun döneme yaymak suretiyle yarattığı avantajlı durum, faiz giderlerinin bütçe üzerinde yarattığı baskı sebebiyle dezavantaja dönüşme ve yerel yönetimleri mali krize sokma riskini de taşımaktadır. Bu sebeple temelde hemen her üye ülkede yerel yönetimler borçlanma yoluyla kaynak yaratmakta serbest olmakla beraber, yerel yönetimler merkezi devletin sahip olduğu gibi vergi gelirleri yaratma esnekliğine sahip olmadıkları için bazı sınırlamalar söz konusu olabilmektedir. $\mathrm{Bu}$ sınırlamalar borçlanma yoluyla elde edilen kaynağın yalnızca yatırımların finansmanında kullanılmasına izin verilmesi, cari giderler için borçlanma yolunun kapalı olması kuralı uygulanması (bu kural tüm Avrupa ülkelerinde geçerlidir) veya toplam borç oranının önceden belirlenmiş üst sınırları aşmaması gibi biçimler alabilmektedir. Son yıllarda, Amsterdam Anlaşmasının İstikrar ve Büyüme Paktı'nın ${ }^{39}$ etkisiyle yerel yönetimlerin borçlanma yoluyla kaynak yaratma yolu yerel yönetim bütçe kontrolü ve özellikle harcama kontrolü ile ayrıca sınırlamalara tabi tutulmaktadır. Hemen hemen tüm üye ülkelerde ulusal istikrar paktları yoluyla yerel yönetim harcamaları sınırlandırılmaktadır. Örneğin İtalya'da belirli harcama sınırlarını aşan yerel yönetimlere borçlanma yolu kapatılmaktadır. İsveç'te ise borçlu yerel yönetimlerin iki yıl içinde bütçe denkliği sağlaması zorunlu hale getirilmiştir.

Avrupa Birliği yerel yönetimlerinin tek paraya geçiş sonrası borçlanma imkanları üzerinde iki farklı etki yarattığı düşünülmektedir. Öncelikli olarak yaratılan olumlu etki özellikle 2000'li y1llarda güçlenen tek para nedeniyle yerel yönetimlerin Avrupa sermaye piyasalarından kolay, güvenilir ve daha ucuz

39 Euro alanında ülkelerin aşırı bütçe açıklarını engellemek için önlemler paketi olarak tanımlayabileceğiz İstikrar ve Büyüme Paktı iki ayrı düzenlemeden oluşmaktadır. İlki önleyici adımda üye ülkelerin ekonomi politikalarını koordine etme ve bütçe pozisyonları izlemeye ilişkin düzenlemeler, diğeri ise üye devletlerin Birliğin izin verdiği bütçe açığı sınırını aşması halinde uygulanacak tedbirlere ilişkin düzenlemelerdir. Ayrıntıları için bkz. Règlement $n^{\circ}$ 1466/97 du Conseil du 7 juillet 1997 relatif au renforcement de la surveillance des positions budgétaires ainsi que de la surveillance et de la coordination des politiques économiques, JOCE L 209 du 2.8.1997, p. 1-5; Règlement $n^{\circ} 1467 / 97$ du Conseil du 7 juillet 1997 visant à accélérer et à clarifier la mise en oeuvre de la procédure concernant les déficits excessifs, JOCE L 209 du 2.8.1997, p. 6-1. 
borç kaynaklar elde etmesidir (CES, 2001: II-63). Bunda Avrupa'daki banka ve kredi kuruluşları arasındaki rekabetin etkisi de bulunmaktadır. İkinci olumsuz etki ise Euro bölgesi içinde uygulanmakta olan maliye politikası sebebiyle yerel yönetimlerin borçlanma yoluyla kaynak yaratma yolunun merkezi devletler tarafından sınırlanması isteğidir. Bazı üye devletlerde kaynak çeşitliliğindeki artışa rağmen bu sınırlamanın yerel yönetim yatırımlarında daralma yaratması yönünde yaygın bir görüş bulunmaktadır. Genel eğilim, 1990'ların sonundan 2000'lı yılların başına kadar, yerel yönetimlerde borçlanmanın Avrupa Birliği ülkelerinde toplam kamu borçlarına kıyasla daha hızlı bir biçimde azaldığıdır. Benzer şekilde gayri safi hasıla içinde yerel yönetim borçlarının oranı da azalmıştır (Dexia, 2003: 12). Ancak 2002'den itibaren Birlik içinde yerel yönetim toplam borçlarında artış görülmüştür (toplam borçların \% 8,6's1 ve gayri safi hasılanın $\% 5,4$ 'ü).

Birlik içinde Federal ülkelerde, genel olarak borçlanmanın nispeten az kullanılan bir yöntem olduğu görülmektedir. Bu durumda genelde GSMH'nın $\%$ 3-5'i civarında bir oran söz konusudur. En düşük borç oranı ise Yunanistan'da ( \% 0,6) en yüksek ise İspanya $(\% 9,1)$ ve Hollanda'da $(\%$ 9,3)'dır (Dexia, 2003:12). Yerel vergiler yönünden oldukça zayıf görünen Hollanda bu açıdan yerel yönetim finansmanında zorunlu olarak merkezi devlet transferleri ve borçlanma araçlarına en çok başvuran ülkelerin başında gelmektedir. Ancak yerel yönetim harcamaları açısından Avrupa ülkeleri arasında önde giden Hollanda için bu anlamda yerel özerklik ile yerel vergi özerkliği farklı anlamlar ifade etmektedir.

Toplam kamu borçları içinde yerel yönetim borçlarının oranları konusunda ise devlet sistemleri ile açık bir bağlantıdan bahsetmek pek mümkün değildir. Örneğin, federal yapıdaki Belçika ve Almanya'da toplam borçlar içinde yerel yönetim borçları \% 5 ile \% 10 arasında değişmektedir. Aynı şekilde üniter Danimarka, Finlandiya ve İsveç’te de buna yakın oranlar söz konusudur. Yerel yönetim gelir kaynakları içinde borçlanmanın payı ise yatırım faaliyetlerinin yoğunluğu ve diğer kaynakların yapısı oranında ülkelere göre değișmektedir. Örneğin, İskandinav ülkelerinde, İrlanda ve Yunanistan'da toplam gelir kaynakları içindeki payı \% 2-3 gibi çok düşük bir orandır ki Avrupa Birliği içinde bu istisnai bir durumdur. Çünkü pek çok ülkede genelde \% 8 gibi bir paya sahiptir (İspanya, Fransa, Hollanda ve Belçika) (Dexıa, 2003: $12)$.

Genelde Birlik ülkelerinde borçlanmadan elde edilen gelir mutlaka yatırımları finanse etmekte kullanılmaktadır. Ancak istisnai olarak, Almanya, Fransa ve Belçika örneğinde olduğu gibi, borçların yeniden yapılandırılması için, kamu işletmelerinin sermayelerine katılımda ve yerel yönetim birliklerinde kullanıldığı da olmaktadır. 


\section{Sonuç}

Serbest piyasa ve küçülen devlet anlayışının yerel yönetim boyutunda doğrudan mali etkileri olması kaçınılmazdır. Ancak artan yerel özerkliğe karşılık yerel yönetimlerin kaynak özerkliği konusu daha tartışmalı görülmektedir. Avrupa Birliği içinde homojen olmayan ulusal yapılarda yerel özerkliğin her zaman yerel vergi özerkliği anlamına gelmediği de anlaşılmaktadır.

Avrupa Birliği'nin yerel yönetimler üzerindeki bölgesel politika yoluyla yarattığ1 olumlu doğrudan mali etkinin yanı sıra Maastricht kriterlerinin yarattığı olumsuz dolaylı etki mali özerklik konusuyla da yakından ilintili görülmektedir. Bütçe açıkları ve borçlanma oranlarından kaynaklanan bu etki ulusal vergilendirme ve vergi uyumlaştırması ile birlikte yerel yönetimler için vergilere dayalı yeni kaynakların getirilmesi imkanını sınırlandırmaktadır. Birlik üye ülkelerinin çoğunda gerçekleştirilen reformlar sonucu yerel yönetimlerin mali olarak önemli değiş̧iklikler geçirdiği gözlenmektedir. İspanya, İtalya, Belçika, Fransa gibi ülkelerde yakın geçmişte izlenen gelişmeler merkezi devletle yerel yönetim birimleri arasındaki görev ve yetki bölüşümünün yeniden yapılandırılmasına ve yerel birimlerin yetki alanlarının genişlemesine sebep olmuştur. Bu durum serbest dolaşım nedeniyle, özellikle sunulan kamu hizmetleri yönünden rekabet eden yerel yönetimler için genel olarak merkezi devlet transferleri ve verimli vergilerden elde edilen hasılatlardan pay verme biçimindeki gelişmeleri teşvik etmektedir. Ancak transfer ve payların kullanımı yerel birim tarafindan serbestçe belirlenmediği sürece görünenin aksine yerelleşmeden çok merkezileşme eğilimini taşıdığ 1 düşünülmektedir.

\section{Kaynakça}

AUBY, Jean-François (1982), Les sevices publics locaux (Paris: PUF, Que sais-je, no. 2023).

BARBIER, Valérie/FROIS, Pierre/LE MASNE, Pierre (non- daté), (Développement durable et les services publics locaux, Une Evaluation de la Méthodologie RESPECT (Rapport de recherche effectué pour la GRALE, Université de Paris I).

BAȘARAN YAVAȘLAR, F. (2002), "Rekabet Sistemi Zoru Gerçekleștiriyor mu? Avrupa Birliği Ve Konsolide Bir Kurumlar Vergisi Matrahı," Avrupa Birliğine Geçiș Süreci ve Türk Kamu Maliyesinin Uyumu (17. Maliye Sempozyumu, 22-25 Mayıs 2002 Fethiye, Türmob Yayınları, 185: 351-381).

BETTINGER, Christian (1994), "Existe-t-il une conception communautaire de la gestion des services publics locaux?," La Gestion des services publiques locaux dans l'Europe de demain (Paris: Litec).

BOUVIER, Michel, Les finances locales (Paris: LGDJ, Collection Systèmes, 2ème édition).

BRODWAY, Robin/ROBERTS, Sandra/SHAH, Anwar (1994), Fiscal Federalism Dimension of Tax Reforms in Developing Countries (Washington: World Bank Policy Research Working Paper 1385, November 1994). 
BYRNE, Tony (1994), Local Government in Britain (Suffolk: Penguin Books, Sixth Edition).

CAN, İsmail (2004), "Almanya'da Devletin Yapısı ve Vergi Sisteminin Anayasal Temelleri," Maliye Dergisi, 145: 37-96.

CLERGERIE, J-L. (1997), Le principe de subsidairité (Paris: Ellipes, Collection Droit en question).

COMITE des REGIONS (1995), Revision du Traité sur l'Union européenne (Rapporteur: Jordi PUJOL, Bruxelles, le 21 avril 1995), http://europa.eu.int/en/agenda/igc-home/eudoc/regions/crf_fr.html.(20/4/2006).

COMMISSION EUROPEENNE (CE) (2000), Inventaire des Impôts Perçus dans les Etats Membres de l'Union Européenne (Luxembourg: 17ème édition).

CONSEIL DE l'EUROPE (1985), Charte Européenne de l'Autonomie Locale (15/10/1985, Strasbourg), $\quad$ http://conventions.coe.int/Treaty/fr/Treaties/Html/122.htm. $(10 / 3 / 2005)$.

CONSEIL ECONOMIQUE ET SOCIAL (CES) (2001), L'avenir de l'autonomie financière locale (Rapporteur J.P Brunel), 11 juin 2001) http://www.conseil-economique-etsocial.fr/presidence/communique/communique.asp?fic=CO012401 (1/3/2006).

DARBY, J./MUSCATELLI, A./ROY, G. (2002), Fiscal Federalism and Fiscal Autonomy : Lessons fort he UK from Other Industrialized Countries, University of Glasgow, September 2002, http://www.york.ac.uk/depts/econ/seminars/papers/darby_fullpaper.pdf. $(2 / 6 / 2004)$

DEXIA (2003), Finances locales dans l'Union européenne:1997/2002 (Notes de conjoncture, novembre 2003).

ESEN, Selin (2004), "Avrupa Birliği Bölgeler Komitesi," Ankara Üniversitesi S.B.F.Dergisi, 2004/4: 89-122.

FRIZON, Richard/MARAND, A-C./RENARD, Sophie/ SCARBONCHI, François (2002), La perception de l'autonomie financière des collectivités locales en Europe: Quels enseignements pour la France? (Strasbourg: CNPFT, Institut Nationale des Etudes Territoriales).

GÖZÜBÜYÜK, Șeref (1991), Yönetim Hukuku (Ankara: S Yayınları).

GUGLIELMI, Gilles J.(1994), Introduction au droit des services publics (Paris: LGDJ, Série Droit Public).

GÜNDAY, Metin (1997), İdare Hukuku (Ankara: İmaj).

http://grale.univ-paris1.fr/pgscient/1\%200range/RappFrois.pdf (16/5/2006). http://www.dexiaclf.fr/abonnes/pages/monde_local/donnees_budgetaires/note_con joncture/doc/NdCEF.pdf

JOSSA, Edward/SEMO, Igor (1990), Les finances locales, La décentralisation inachevée? (Paris: La documentation française, Collection Notes et Etudes, $\mathrm{n}^{\circ}$ 4911).

JOUMARD, Isabelle Joumard/KONGSRUD Per Mathis (2003), "Les Relations Financières entre l'Etat et les Collectivités locales," Revue économique de l'OCDE , 36/l: 169-254.

KARAHANOĞULLARI, Onur (2002), Kamu Hizmeti, Kavram ve Hukuksal Rejim (Ankara: Turhan Kitabevi).

LE CACHEUX Jean, (1996), "L'intégration européenne et fiscalité," Impôts et réforme fiscale, Cahiers Français, no 274, janvier-février: 65-75.

LGDK, LOCAL GOVERNMENT DENMARK (2006), Reform of the Municipal System in Denmark, http://www.kl.dk/359504 (29/5/2006).

MARAND, Anne-Claire/FRIZON, Richard/ RENARD, Sophie/SCARBONCHI, François (2002), Les finances locales en Europe (Rapport préparé pour Europa, le 20 octobre 2002. http://www.prospeur.unilim.fr/fr/prospeur/telechargements/finances/finances\%20l ocales.pdf. (20/4/2005).

MINISTERE DE L'INTERIEUR (MDI)(2004), Rapport de la Commission de la Réforme de la Taxe Professionnelle (21 décembre 2004, annexe 14 Comparaison Internationale), 
- Ankara Üniversitesi SBF Dergisi • 63-1

http://www.dgcl.interieur.gouv.fr/publications/rapports/rapport_com_taxe_prof/Fi che14.pdf $(9 / 6 / 2006)$.

NADAROĞLU, Halil (1998), Mahalli ldareler (İstanbul: Beta, 6.Bası).

OECD (1994), State Budget Support to Local Government in Eastern and Western Europe (Paris: report by Prof. Gerard Marcou)

ONAR, Sıddık Sami (1952), Idare Hukukunun Umumi Esasları (İstanbul: Marifet Basımevi).

PARLEMENT EUROPEEN (PE) (1997), Entreprises Publiques et Services Publics Économiques dans l'Union Européenne (Document de Travail, SérieEconomie W-21, mai 1997), http://www.europarl.eu.int/workingpapers/econ/w21/sum-toc_fr.htm. (5/3/2005).

POUGNAUD, Pierre (1992), Les collectivités locales et l'Europe (Berger-Levrault).

SENAT de la République Française (2000), Les services d'intérêt général en Europe (Rapport d'information, Annexe au procès-verbal de la séance du 16 novembre 2000, Rapporteur M. Hubert HAENEL), http://www.senat.fr/rap/r00-082/r00-082.html. $(25 / 5 / 2005)$

SHOUP, Carl (1969), Public Finance (Great Britain: Weidenfeld and Nicolson).

UNION EUROPEENNE (2001), L'Europe qu'il nous faut (Document de travail, 25 septembre 2001), http://europa.eu.int/futurum/documents/other/oth250901_fr.pdf (18/4/2005).

ÜLKMEN, .i. Hakkı (1960), Mahalli Idareler Maliyesi Dersleri (Ankara: Ankara Üniversitesi Siyasal Bilgiler Fakültesi Yayınları no. 103/85). 